\title{
The Changing Color of Welfare? How Whites' Attitudes toward Latinos Influence Support for Welfare ${ }^{1}$
}

\author{
Cybelle Fox \\ Harvard University
}

\begin{abstract}
This article uses the National Election Study to consider how stereotypes about Latinos influence white support for welfare. It shows that whites' stereotypes about Latino work ethic grow more positive as the size of the Latino population increases, suggesting positive effects of contact. Moreover, the effect of whites' stereotypes about Latino-but not black-work ethic on support for welfare is contingent on ethnic context. In areas with few Latinos, the lazier whites think Latinos are, the less whites want to spend on welfare. However, in areas that are disproportionately Latino the more hardworking whites think Latinos are (controlling for whites' stereotypes about blacks), the less whites want to spend on welfare as well. This last result, this article argues, is the product of a social comparison between black and Latino work ethic.
\end{abstract}

\section{INTRODUCTION}

Few social policy issues have aroused as much ire among politicians as welfare. The political rhetoric and media images that surround the public debate about welfare have often been inflammatory, derogatory, and racially coded. Former president Ronald Reagan's characterization of the

\footnotetext{
${ }^{1}$ Special thanks are given to Lawrence Bobo, Jennifer Hochschild, David Ellwood, Christopher Jencks, William Julius Wilson, Mario Small, Larry M. Bartels, the AJS reviewers, and participants in the Harvard Proseminar on Inequality and Social Policy for their helpful comments on previous versions of this article. Any errors are the sole responsibility of the author. Preparation of this article was supported in part by a National Science Graduate Research Fellowship awarded to the author and by a National Science Foundation integrative graduate education and research traineeship (IGERT; grant 98070661). Direct correspondence to Cybelle Fox, Department of Sociology, William James Hall, 33 Kirkland Street, Cambridge, Massachusetts 02138. E-mail: fox@fas.harvard.edu
}

(C) 2004 by The University of Chicago. All rights reserved. 0002-9602/2004/11003-0003\$10.00 


\section{Changing Color of Welfare}

Cadillac driving welfare queen is probably the most memorable instance, ${ }^{2}$ but the 1990s were no exception to this kind of rhetoric. During the debates about welfare reform two congressmen stood on the House floor and compared welfare recipients to wild animals-wolves and alligatorswho had lost their ability to forage in the wild (Congressional Record 1995). The media has done its part to fan the flames, often portraying mothers on welfare as promiscuous, lazy, and-especially when the depiction is unfavorable-black (Clawson and Trice 2000; Gilens 1996a, 1999; Williams 1995).

It should come as no surprise then that recent research shows that racial stereotypes help explain why many white Americans are no fans of welfare. Gilens $(1995,1996 b, 1999)$ argues that antiwelfare sentiment is driven largely by whites' negative stereotypes of black people's work ethic. He argues that whites hate welfare because they believe that most people on the welfare rolls are black and that blacks are in general lazy and therefore undeserving of government help. ${ }^{3}$ There are also indications that racial context - the percentage of blacks in a city or state-may influence support for welfare (Wright 1976). Luttmer (2001) has found that support for welfare among nonblacks decreases the more black welfare recipients there are in a respondent's neighborhood, city, or state but is unaffected by the share of nonblack welfare recipients. If racial stereotypes and racial context are driving forces behind antiwelfare sentiment, how might public opinion about welfare be affected by the rapidly changing racial and ethnic demographics nationwide?

In the last decade of the 20th century, the proportion of Latinos in this country grew by nearly $50 \%$. By the end of the 1990s the number of Latinos equaled the number of African-Americans. This racial and ethnic demographic shift is apparent in the ranks of people who are poor and those who are on welfare. ${ }^{4}$ In 1990 only $17 \%$ of people on welfare, which was then called Aid to Families with Dependent Children (AFDC), were

\footnotetext{
${ }^{2}$ This remark of President Reagan's appeared in the New York Times, February 15, 1976 (cited in Edsall and Edsall 1992).

${ }^{3}$ Gilens assumes that stereotypes drive antiwelfare sentiment. However, it is possible that a third variable is driving both antiwelfare sentiment and stereotypes about blacks or, perhaps more likely, that antiwelfare sentiment drives stereotypes. If whites think that welfare makes people lazy, and that people on welfare are predominantly black, they may generalize the stereotype to the entire group. For the purposes of this article, I assume at the outset, like Gilens, that stereotypes drive antiwelfare sentiment. It is likely, however, that causation runs in both directions and that one reinforces the other. ${ }^{4}$ According to the 1990 census, $49 \%$ of the nation's poor were white non-Hispanic, $29 \%$ were black, $18 \%$ were Hispanic, and $3 \%$ were Asian. By 2000, the percentage of the poor who were Hispanic and Asian had increased to $23 \%$ and $4 \%$, respectively, while the share of whites and blacks among the poor had fallen slightly to $47 \%$ and $25 \%$.
} 
American Journal of Sociology

Latino. By 2000, welfare had a new name, Temporary Assistance to Needy Families (TANF), ${ }^{5}$ and the percentage of Latino recipients had grown to $25 \%$. Over this same time period, the percentage of people on welfare who were black remained largely constant (at roughly 39\%), as did the percentage of Asians (roughly 3\%). Latinos, then, largely supplanted nonLatino whites, whose share dropped from $38 \%$ in 1990 to $31 \%$ in 2000 (U.S. Department of Health and Human Services 2002).

Despite these significant demographic changes, little work has been done on the relationship between whites' views of Latinos and their support of redistributive policies such as welfare-this despite the fact that many whites clearly view Latinos, on the whole, as welfare dependent. The 1990 General Social Survey asked respondents whether they thought various racial/ethnic groups were more likely to prefer living off welfare or being self-sufficient. Among whites $59 \%$ believed that blacks generally preferred to live off welfare rather than be self-sufficient, $46 \%$ thought the same of Hispanics, while only $18.5 \%$ and $3 \%$ attributed the characteristic of welfare dependence to Asians and whites, respectively (Bobo and Kluegel 1997; Davis and Smith 1990).

Similarly, no studies consider whether or how ethnic context influences the relationship between whites' stereotypes and their welfare-spending preferences. Proximity to African-Americans has been shown to decrease whites' support for welfare. Does proximity to Latinos do the same?

This article will attempt to fill these gaps. It will examine whether whites' stereotypes about Latino work ethic are related to their welfarespending preferences. Furthermore, it will examine how racial and ethnic context influences the prevalence of stereotypes about blacks and Latinos as well as the impact of those stereotypes on support for welfare.

\section{LITERATURE REVIEW}

The historic and enduring relationship between race and the welfare state is well established (Brown 1999; Edsall and Edsall 1992; Gilens 1995, 1996a, 1996b, 1999; Lieberman 1998; Luttmer 2001; Peffley, Hurwitz, and Sniderman 1997; Quadagno 1990, 1994; Wright 1976). Nonetheless, Americans' contemporary ambivalence toward welfare has often been ex-

${ }^{5}$ The passage of the Personal Responsibility and Work Opportunity Reconciliation Act of 1996, better known as welfare reform, replaced AFDC with TANF, thereby eliminating the entitlement to welfare, imposing a five-year lifetime limit on federal benefits, and devolving much of the responsibility for the program-through the use of block grants-to the states. The new law also required that states adopt stringent new work requirements for most welfare recipients or cut their caseload size. 
plained primarily in terms of economic self-interest or principled individualism.

Theories of economic self-interest generally postulate that American voters have a difficult time supporting policies that do not directly benefit them, or people like them. Means-tested programs such as TANF therefore garner little public support, except among those who have already made use of them, think they might use them in the future, or have friends or family who benefit from the program. Empirical evidence indicates that support for welfare is indeed inversely correlated to family income and positively correlated to previous welfare receipt (AuClaire 1984; Gilens 1995). Using data from the 1983 Detroit Area Study, Hasenfeld and Rafferty (1989) found that people who were socioeconomically vulnerablepeople who were low-income, with low levels of education, nonwhite, and young - and therefore more likely to benefit or to know someone who benefited from means-tested programs (such as AFDC and Food Stamps) were more supportive of them. Cook and Barrett (1992) also found that self-interest is one factor among others-mainly political predispositions, attributions of recipient deservingness, and attributions of program effectiveness-that explain weak support for means-tested programs. The notion that economic self-interest is at the root of such ambivalence has led some to argue that only universal welfare programs will garner meaningful and sustained public support (Cook and Barrett 1992; Skocpol 1991). However, theories that emphasize self-interest are generally unable to explain near universal support for programs to the poor that do not provide direct cash subsidies such as job training or food assistance (Gilens 1999).

Other authors have argued that a principled belief in individualism, a core American value noted as far back as the 1800 s by Alexis de Tocqueville, is at the root of many Americans' opposition to welfare (Feldman and Zaller 1992; Marmor, Mashaw, and Harvey 1990; Mead 1986). Individualism is a broad political concept that defies easy definition, but authors who make this argument often focus on economic individualism, defined by Feldman and Zaller (1992) as "the commitment to merit as the basis for the distribution of rewards in society and the belief that people ought to work hard." Since welfare is means tested and noncontributory (unlike Social Security, for example), welfare recipients are perceived as getting "something for nothing" and thus violating core values of bootstrapping and rugged individualism. On the basis of an analysis of open-ended questions, Feldman and Zaller (1992) find that people who oppose the welfare state justify their beliefs based upon values and principles such as individualism and limited government.

Gilens (1999) argues that while self-interest and individualism certainly play an important role in American ideas about welfare, racial attitudes- 
American Journal of Sociology

in particular the widely held stereotype that blacks are lazy ${ }^{6}$-are even more important to understanding why so many Americans hate welfare. In a model that simultaneously assesses the impact of basic demographic characteristics, economic self-interest, individualism, political views, racial attitudes, and welfare recipient deservingness, Gilens finds that the stereotype that blacks are lazy is one of the most powerful predictors of welfare support, second only to the perception that welfare recipients are undeserving, which is itself highly correlated with the stereotype about black work ethic. Moreover, in order to show that this racial stereotype is truly at the heart of timid support for welfare and not generalized stereotypes about the work ethic of all people on welfare, Gilens uses what he terms "The Welfare Mother Experiment" (see also Peffley et al. 1997). In this experiment, respondents were randomly assigned to answer one of two versions of a question about welfare mothers. All respondents were asked about their impressions of a female welfare recipient in her early 30s who has a 10-year-old child and has been on welfare for the past year. The question differs for the two groups only in the ascribed race of the welfare recipient: half the respondents are told the mother is white; half are told she is black. All the respondents are then asked how likely it is that the woman described will try hard to find a job and how likely it is that the woman will have more children in order to get a bigger welfare check. Gilens finds that the stereotypes of black welfare recipients are almost twice as strong as stereotypes of white welfare recipients in predicting opposition to welfare spending, indicating that racial stereotypes are central factors underlying white opposition to welfare.

There is no literature that seriously or thoroughly examines whether whites' stereotypes about Latinos influence their support for spending on welfare. Ethnographic research often hints at the possibility that whites' views of blacks' and Latinos' (especially Puerto Ricans) relationship to the welfare state are comparable (Edsall and Edsall 1992; Rieder 1985). However, some qualitative work suggests that whites' attitudes about Latino immigrants and welfare are generally not as salient or strongly felt as views about blacks and welfare (Lamont 2000). Gilens (1999) does not include stereotypes of Latinos in his models, rationalizing their exclusion because he finds they are insignificant in a partial model using the 1994 General Social Survey that controls for stereotypes about blacks

\footnotetext{
${ }^{6}$ A stereotype is "a set of beliefs about the personal attributes of members of a particular social category" (Ashmore and Del Boca 1981, p. 13). Racial stereotypes can be positive or negative; in either case, racial stereotyping "involves projecting assumptions or expectations about the likely capacities and behaviors of members of a racial or ethnic group onto members of that group" (Bobo 2001).
} 


\section{Changing Color of Welfare}

as well as for age, sex, family income, education, and region of residence. ${ }^{7}$ Gilens does suggest, though, that it is likely that those stereotypes will become salient as the share of Latinos on welfare rises.

The Influence of Racial and Ethnic Context

For my purposes, racial and ethnic context can matter in three distinct ways: it can influence the prevalence of racial and ethnic stereotypes, it can influence support for welfare, and it can influence the impact of racial and ethnic stereotypes on support for welfare. A wide body of research has considered the impact of racial context on white racial animosity in general, but almost all of this research has focused exclusively on whites' views of African-Americans. The threat hypothesis suggests that proximity to blacks may increase white racial animosity because the presence of a large number of blacks threatens whites' political, social, and economic privileges. On the other hand, the contact hypothesis implies that racial isolation may breed more racial resentment because whites are deprived of the opportunity to have their stereotypes about blacks challenged.

Most recent studies on racial context indicate that proximity breeds contempt. First advanced by Key (1949), the threat hypothesis suggests that white prejudice increases in proportion with the size of the surrounding black community. Many published studies have shown that a greater percentage of blacks in a state, county, or metropolitan area increases white racial animosity and decreases support for racially tinged policies such as busing, affirmative action, and welfare (Bobo 1988; Fossett and Kiecolt 1989; Glaser 1994; Quillian 1996; Taylor 1998; Wright 1976). Oliver and Mendelberg (2000) consider how both the racial and the economic context of the respondent's environment influences racial attitudes and support for racially tinged policies. Economic contexts are important because the threat hypothesis suggests that low-income whites will feel greater threat from blacks than will their middle- or upper-class counterparts since low-income whites are most likely to compete with blacks for social, economic, and political goods. Oliver and Mendelberg demonstrate that negative stereotypes are more prevalent among people in zip codes with fewer college graduates, but that the effect of \%black is not statistically significant at the zip code level. At the metro level, \%black

\footnotetext{
${ }^{7}$ However, according to my calculations, even stereotypes about African-Americans are insignificant using the 1994 GSS when additional controls, such as political views and individualism, are included in the model, making it an unsatisfactory test of the hypothesis that whites' stereotypes of Latinos influence their preferences about welfare spending.
} 
American Journal of Sociology

is statistically significant though indicating that severe residential segregation may reduce the impact of interracial threat. These findings did not apply to support for welfare, however, where Oliver and Mendelberg found no contextual effects. They conclude that an "environment's racial and status composition can shape its residents' opinions on race targeted policies, but only where the contextual parameter coincides with real racial competition" (2000, p. 583). Support for welfare is not influenced by local racial context, they argue, because decisions about welfare spending and administration are made at the state and national levels.

It is not clear whether the threat hypothesis can be applied to other racial and ethnic groups. Taylor (1998) considers the effect of both racial and ethnic context on prejudice and opposition to racially tinged policies and finds that "numbers count"-but only for blacks. While proximity to blacks generally increases white racial animosity, proximity to Latinos and Asians does not. In fact, though not statistically significant, the sign on the coefficient for \%Latino in Taylor's model runs in the opposite direction from the sign on the coefficient for \%black, suggesting that proximity to Latinos may actually decrease white racial animosity toward that group.

Another body of literature suggests that, under the right circumstances, contact with blacks may decrease the prevalence of negative stereotypes (Allport 1954). Under this classical prejudice model, aversion to racial or ethnic groups is based on individual psychological dispositions and is largely irrational (Bobo and Hutchings 1996). Stereotypes about outgroups thrive in racially isolated locales because of ignorance. Kinder and Mendelberg (1995) estimate the impact of prejudice on various public policy opinions (including support for welfare) and examine whether the impact of prejudice on policy preferences is affected by the presence of blacks in the respondents' neighborhood. They find that contact with blacks-whether whites have diverse workplaces, neighborhoods, or churches-generally operates to diminish the impact of prejudice on welfare. However, because of large standard errors resulting from methods designed to deal with endogeneity, the results are not significant.

The contact and threat hypotheses, it must be noted, are not necessarily mutually exclusive. While proximity may decrease the prevalence of certain stereotypes, whites may nonetheless feel that their economic, political, or social position is threatened when the proportion of an out-group rises. Furthermore, while most of the work on the threat hypothesis employs the \%black in the state, county, or metropolitan area, work on the contact hypothesis often employs measures of actual contact, such as the diversity of one's neighborhood, place of work, or circle of friends. It is possible for whites to live in a state with a large percentage of blacks without ever coming into direct or meaningful social contact with blacks. In fact, given 


\section{Changing Color of Welfare}

the high rates of residential segregation (Sigelman et al. 1996; Massey and Denton 1993), this scenario is not at all unlikely. Nonetheless, for whites interracial contact is more likely in areas with higher concentrations of nonwhites (Sigelman et al. 1996). This article will not attempt to test whether actual social contact with blacks and Latinos influences the prevalence of stereotypes among whites or the impact those stereotypes have on welfare-spending preferences. In this sense it is not a true test of the contact hypothesis, which might require information not only on the frequency of contact but on the quality of those contacts and the conditions under which contact occurs, ${ }^{8}$ not to mention methods to address legitimate concerns about self-selection. ${ }^{9}$ This article will instead consider whether a more diverse racial and ethnic context (operationalized as \%black and $\%$ Latino at the state and county levels) leads to greater white racial animosity or, conversely, whether racial isolation is at the root of racial resentment. ${ }^{10}$

\section{Hypotheses}

Since Gilens's work shows that whites' stereotypes about blacks are negatively related to their welfare-spending preferences,

\footnotetext{
${ }^{8}$ Allport (1954) acknowledged that mere contact will not always work to diminish prejudice. For it to be effective, contact should first "not take place within a competitive context. Second, it must be sustained rather than episodic. Third, the contact must be personal, informal and one-to-one. Fourth, the contact should have the approval of any relevant authorities. Finally, the setting in which the contact occurs must confer equal status on both parties rather than duplicate the racial status differential" (Jackman and Crane 1986, p. 461).

${ }^{9}$ Much of the work on the contact hypothesis has been criticized for its failure to deal successfully with issues of self-selection. Individuals who have more frequent contact with out-group members are likely different in some unobservable ways from individuals who have less contact. Without random assignment into settings that guarantee contact, or some sort of natural experiment (such as looking at military assignments, workplace diversity, or college roommates), it is difficult to effectively address those concerns.

${ }^{10}$ There is always the worry that individuals self-select into a particular racial or ethnic context, making people who live in more diverse settings different in unobservable ways from people who live in more homogeneous areas. If we believe that such selfselection is occurring, we may be wary of making causal statements like "racial isolation is at the root of racial resentment." This concern is valid, and I have done nothing in this article to guard against this possibility. But I would argue that self-selection is more problematic the smaller the contextual unit of analysis. Whites' choices about which neighborhood or block to live on is more likely to be influenced by racial and ethnic context than their decision about which state to live in. Furthermore, it is difficult to imagine why whites who feel more animosity toward blacks would self-select into disproportionately black areas (see also Schuman 2000). Similarly, there is little reason to think that blacks would be drawn to a more hostile environment (Taylor 1998).
} 
American Journal of Sociology

Hypothesis 1.-Whites who think either blacks or Latinos are lazy are more likely to want to decrease spending on welfare.

The threat hypothesis suggests that proximity breeds contempt.

Hypothesis 2.-Whites who live in an area with a large number of blacks are more likely to stereotype blacks as lazy, to want to decrease spending on welfare, and to let their negative stereotypes about blacks influence their welfare-spending preferences.

Similarly,

Hypothesis 3.-Whites who live in an area with a large number of Latinos are more likely to stereotype Latinos as lazy, to want to decrease spending on welfare, and to let their negative stereotypes about Latinos influence their welfare-spending preferences.

Conversely, the contact hypothesis suggests that proximity breeds amity.

Hypothesis 4.-Whites who live in an area with a small number of blacks are more likely to stereotype blacks as lazy, to want to decrease spending on welfare, and to let their negative stereotypes about blacks influence their welfare-spending preferences.

Similarly,

Hypothesis 5.-Whites who live in an area with a small number of Latinos are more likely to stereotype Latinos as lazy, to want to decrease spending on welfare, and to let their negative stereotypes about Latinos influence their welfare-spending preferences.

\section{DATA AND MEASURES}

Data

In this article I have made use of the National Election Study (NES). The NES is a nationally representative election survey that is conducted every two years and contains both pre- and postelection components. The survey is designed to capture Americans' social backgrounds, political views, opinions on various public policy issues, and social values.

Three different years of the NES were employed: the 1992, 1996, and 2000 surveys (Miller et al. 1993; Rosenstone et al. 1997; Burns et al. 2001). The availability of three separate years of data on which to test the hypotheses is fortuitous since many changes took place between 1992 and 2000 that may affect our results-including the sizable growth of the Latino population over the decade and the advent of welfare reform. How these two events will affect the results is unclear. The growth of the Latino population may increase whites' perceptions of threat and reinforce negative stereotypes, or it could weaken whites' stereotypes about Latinos by providing more opportunities for actual social contact between the two groups. Welfare reform eliminated the entitlement to welfare and 


\section{Changing Color of Welfare}

made access to benefits in many cases conditional on work. As a result, stereotypes about work ethic may have become less important in whites' evaluations of welfare after 1996 when the Personal Responsibility and Work Opportunity Reconciliation Act (PRWORA)-better known as welfare reform-was passed. However, welfare reform also gave state legislators far greater discretion in setting policy with regard to eligibility standards, benefit levels, and program rules, which may have increased the importance of state-level contexts. Analyses in this article are based on interviews with 4,547 white non-Hispanic respondents: 1,880 in 1992, 1,321 in 1996, and 1,346 in 2000.

\section{Measures}

The dependent variable in most of the models in this article is a measure of support for government spending on welfare. Respondents were asked whether government spending on welfare should be increased, decreased, or kept about the same. ${ }^{11}$ Responses were scored zero for "decreased," 50 for "kept about the same," and 100 for "increased."

Independent variables used in each of the models consist of basic demographic controls, including sex, age, marital status, and education measured in years. Real family income (1999 dollars) is included as a measure of economic self-interest. Missing cases were imputed, ${ }^{12}$ and the new variable coded on an 11-point scale (from $\$ 0-\$ 10,000$ to $\$ 100,000+$ ) where each point represents a $\$ 10,000$ increase over the previous point. The economic self-interest theory suggests that the more income people have the less they will support government spending on welfare. Though we might not expect that the relationship between family income and support for welfare will be linear (middle-income families may be those most opposed to welfare because they are most burdened by the taxes), Gilens (1995) has shown that allowing for a nonlinear relationship does not increase the power of income as a predictor of attitudes toward welfare.

Measures of political party affiliation and political views are also included in each of our models. Party affiliation is measured on a sevenpoint scale from strong Democrat to strong Republican, with independents falling in between. Political views are measured on a seven-point scale

${ }^{11}$ Gilens (1999) suggests that the public definition of welfare encompasses programs that assist the working-age, able-bodied poor with cash or near cash benefits. An example of a near cash benefit is the Food Stamps Program.

${ }^{12}$ Approximately $11 \%$ of the total sample had missing data on the family income question. Missing cases were imputed using age, race, sex, marital status, respondent's education level, spouses' education level, self-reported social class, and whether the respondent owns or rents a home. The results in this article are not significantly affected by the use of this imputed income variable. 
American Journal of Sociology

from extremely liberal to extremely conservative. Since Republicans and conservatives have historically been less supportive of the welfare state than Democrats and liberals, we expect that the former will be more likely to favor reducing spending on welfare programs (Edsall and Edsall 1992; Gilens 1999).

Each model also has two variables that tap individualism. Gilens (1999) argues that the brand of individualism most pertinent to attitudes about welfare is the preference for limited government and a concern for individual initiative and responsibility. The surveys for all three years ask respondents about their preferences for limited government. All three also ask questions that tap concern with individual initiative and responsibility. Unfortunately, there are no consistent measures of this latter concept across the surveys. In 1992, I make use of a question that asks whether getting ahead through one's own effort is an important quality of being a true American. In 1996 and 2000, I make use of a question that asks whether it is better to be self-reliant or cooperative. (See app. table A1 for a listing of the survey questions for all three years.)

Racial attitude variables that measure the perceived work ethic of various racial and ethnic groups, including blacks and Hispanic-Americans, are also included. This variable is measured on a seven-point scale from "hardworking" to "lazy."

Finally, NES data are merged with census data on the states in which respondents reside, in order to control for states' racial and ethnic composition. If antiwelfare sentiment is driven partially by competition between whites, blacks, and Latinos for resources or group position (real or perceived), as the threat hypothesis implies, then state-level contexts are an appropriate unit of analysis because most welfare policy decisions are made at the state or national levels (Oliver and Mendelberg 2000). Since interracial contact is more likely for whites in areas that have a larger proportion of out-group members, some models were also estimated using county-level data for the 1992 and 1996 NES to determine whether local racial and ethnic context has different effects than state racial and ethnic context. ${ }^{13}$ Census data for 1990 are linked to the 1992 NES, and 2000 census data to the 2000 NES. The racial and ethnic composition for 1995 was estimated using interpolation (assuming linear growth) and applied to the $1996 \mathrm{NES}^{14}$

\footnotetext{
${ }^{13}$ At the time of the writing of this article, the 2000 NES did not have county-level data available for public use.

${ }^{14}$ It is certainly more appropriate to use the racial and ethnic context for the exact year surveyed. But since whites are generally not especially attuned to the precise racial and ethnic composition of their environment-they generally greatly underestimate the \% white-I am not too concerned with my admittedly crude approximation.
} 


\section{Changing Color of Welfare}

All independent political and racial attitude variables are recoded on a zero-to-one scale for ease of interpretation and comparison of results. ${ }^{15}$ High scores are assigned for Republican, conservative, self-reliant, in favor of less government, and lazy. Unless otherwise noted, adding variables for southern residence, the state poverty rate, the state welfare recipiency rate, size of community, average state welfare benefit level, or whites' perception of the work ethic of whites has no significant effect on the results in the models in this article, so they are excluded from most analyses. ${ }^{16}$ See the appendix tables B1-B4 for correlations, means, and standard deviations for all variables before recoding.

\section{RESULTS}

Table 1 contains basic frequencies for variables that measure welfarespending preferences as well as work ethic stereotypes for all three survey years. Antiwelfare sentiment clearly peaks in 1996-the year welfare reform was signed into law-with a majority $(61 \%)$ favoring a reduction in welfare spending. Stereotypes about work ethic are clearly racialized. Across all three years, whites are far more likely to think whites are hardworking than to think the same of either Latinos or blacks. Still whites' views of Latinos' work ethic are more favorable than their views of blacks' work ethic. Over time, whites' views of both black and Latino work ethic improve, especially between 1992 and 1996, but whites' views of Latino work ethic appear to improve at a faster pace.

In table 2, I estimate the relationship between whites' stereotypes about black and Latino work ethic and whites' welfare-spending preferences in a pooled model that includes year dummies and controls for demographic variables, a measure of economic self-interest, individualism, party affiliation, and political views, using ordinary least squares. ${ }^{17}$

Consistent with previous research, there is support for the economic

Indeed, the findings in this article are similar even if I apply 2000 or 1990 census data to the 1996 data set.

${ }^{15}$ I follow Gilens $(1995,1999)$ in rescoring all independent political and racial attitude variables on a $0-1$ scale. Rescoring the political and racial attitudes variables is not an issue because there is no natural scale to these opinion variables.

${ }^{16}$ That these variables have no significant effect on the variables of interest does not mean that they are not significant when placed in the model. I am merely arguing that excluding them from the model does not lead to omitted variable bias.

${ }^{17}$ Because my dependent variable is categorical, ordinal logit regression is methodologically a more appropriate choice. However, the findings in this article do not change significantly if I use an ordinal logit model instead of OLS. I use OLS because it is more commonly used in these types of analyses and the coefficients are more easily interpretable. 


\section{American Journal of Sociology}

TABLE 1

Frequencies (\%) of White Non-Hispanics' Support for Welfare and StEREOTYPES ABOUt WORK ETHIC

\begin{tabular}{|c|c|c|c|}
\hline Variable & 1992 & 1996 & 2000 \\
\hline \multicolumn{4}{|l|}{ Welfare: } \\
\hline Increase $\ldots \ldots \ldots \ldots \ldots \ldots \ldots \ldots \ldots$ & 14 & 9 & 14 \\
\hline Kept same $\ldots \ldots \ldots \ldots \ldots \ldots \ldots \ldots$ & 40 & 30 & 45 \\
\hline 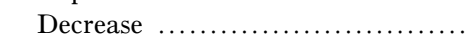 & 46 & 61 & 41 \\
\hline \multicolumn{4}{|l|}{ Beliefs about work ethic: } \\
\hline \multicolumn{4}{|l|}{ About blacks: } \\
\hline Lazy...$\ldots \ldots$ & 35 & 30 & 30 \\
\hline Hardworking & 22 & 25 & 25 \\
\hline \multicolumn{4}{|l|}{ About Latinos: } \\
\hline Lazy .......... & 27 & 20 & 18 \\
\hline Hardworking & 31 & 37 & 41 \\
\hline \multicolumn{4}{|l|}{ About whites: } \\
\hline Lazy $\ldots \ldots \ldots \ldots \ldots \ldots \ldots \ldots \ldots$ & 7 & 6 & 7 \\
\hline Hardworking $\ldots \ldots \ldots \ldots \ldots \ldots$ & 62 & 58 & 58 \\
\hline
\end{tabular}

SourCE. - National Election Study 1992, 1996, and 2000.

NotE. - "Lazy" includes all responses on the lazy side of the scale (5-7) and "hardworking" all responses to the hardworking side of the scale (1-3). Neutral responses (4) are not included in this table.

self-interest theory. Family income is negatively related to support for welfare and is significant at the $5 \%$ level. ${ }^{18}$ If we exclude controls for party affiliation, political ideology, individualism, and racial and ethnic stereotypes - variables that may be partly endogenous to family incomethe size of the family income coefficient doubles. ${ }^{19}$ Not surprisingly, Republican Party affiliation is negatively related to support for welfare, and conservatives are less likely to support welfare than liberals. In fact, strong conservatives have predicted scores on welfare spending that are 22 units lower (on a 100-unit scale) than strong liberals. Finally, variables that tap individualism are negatively related to whites' welfare-spending preferences and are significant at the $1 \%$ level. $^{20}$

\footnotetext{
${ }^{18}$ The results are the same whether we include family income as a continuous variable or as a set of 10 dummy variables.

${ }^{19}$ The family income coefficient without those controls is -1.2 with a $t$-statistic of -5.51 .

${ }^{20}$ My measure of economic individualism differs in 1992 from 1996 and 2000. In order to pool the model, I had to construct dummy variables for the two measures. "Get ahead" was recoded 0,1 where 0 means you think getting ahead through one's own effort is only somewhat or not at all important and 1 means that it is very or extremely important. The "self-reliant" measure in 1996 and 2000 remains the same since it was already coded 0, 1 for disagree or agree.
} 
Changing Color of Welfare

TABLE 2

Ols Predictors of Whites' Spending Preferences on Welfare, Pooled Model

\begin{tabular}{|c|c|c|c|}
\hline Variable & 1 & 2 & 3 \\
\hline Family income $(\$ 10,000) \ldots \ldots \ldots$ & $\begin{array}{c}-.54^{*} \\
(.23)\end{array}$ & $\begin{array}{r}-.59^{*} \\
(.23)\end{array}$ & $\begin{array}{c}-.56^{*} \\
(.23)\end{array}$ \\
\hline Republican & $\begin{array}{c}-6.7 * * \\
(2.0)\end{array}$ & $\begin{array}{c}-6.9^{* *} \\
(2.0)\end{array}$ & $\begin{array}{c}-6.7 * * \\
(2.0)\end{array}$ \\
\hline Conservative $\ldots \ldots \ldots \ldots \ldots \ldots$ & $\begin{array}{c}-22.0 * * \\
(2.8)\end{array}$ & $\begin{array}{c}-22.4 * * \\
(2.9)\end{array}$ & $\begin{array}{c}-21.8^{* *} \\
(2.9)\end{array}$ \\
\hline Get ahead on own (1992) ........ & $\begin{array}{c}-6.3^{* *} \\
(2.2)\end{array}$ & $\begin{array}{c}-6.6^{* *} \\
(2.3)\end{array}$ & $\begin{array}{c}-6.3 * * \\
(2.3)\end{array}$ \\
\hline Self-reliant $(1996,2000) \ldots \ldots \ldots$ & $\begin{array}{c}-6.6^{* *} \\
(1.4)\end{array}$ & $\begin{array}{c}-7.3^{* *} \\
(1.5)\end{array}$ & $\begin{array}{c}-7.0^{* *} \\
(1.5)\end{array}$ \\
\hline Less government is better & $\begin{array}{c}-10.8^{* *} \\
(1.3)\end{array}$ & $\begin{array}{c}-11.0^{* * *} \\
(1.3)\end{array}$ & $\begin{array}{c}-10.8^{* *} \\
(1.3)\end{array}$ \\
\hline Believe blacks are lazy $\ldots \ldots \ldots$ & $\begin{array}{c}-18.1^{* *} \\
(3.0)\end{array}$ & $\ldots$ & $\begin{array}{c}-18.0^{* * *} \\
(3.4)\end{array}$ \\
\hline Believe Hispanics are lazy ...... & $\ldots$ & $\begin{array}{c}-7.3^{*} \\
(2.9)\end{array}$ & $\begin{array}{r}.80 \\
(3.3)\end{array}$ \\
\hline Constant $\ldots \ldots \ldots \ldots \ldots \ldots \ldots \ldots$ & $\begin{array}{l}69.7 * * \\
(4.9)\end{array}$ & $\begin{array}{l}63.2 * * \\
(5.0)\end{array}$ & $\begin{array}{l}68.1^{* *} \\
(5.0)\end{array}$ \\
\hline Adjusted $R^{2} \ldots \ldots \ldots \ldots \ldots \ldots$ & .1643 & .1614 & .1687 \\
\hline 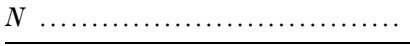 & 3,128 & 3,062 & 3,055 \\
\hline
\end{tabular}

SourCE. - National Election Study 1992, 1996, and 2000.

NotE. - All models include year dummies and controls for age, sex, marital status, and education. Dependent variable is scored 0,50, 100 for decrease, maintain, and increase welfare spending. All political and racial attitude variables are scored on a $0-1$ scale, with high scores for Republican, conservative, self-reliant/get ahead on own, less government, and lazy. Numbers in parentheses are SEs.

$* P<.05$.

** $P<.01$

\section{RACIAL AND ETHNIC STEREOTYPES AND WELFARE}

Consistent with previous studies, whites' stereotypes of blacks' work ethic are negatively related to their welfare-spending preferences and are significant at the $1 \%$ level. That is, the lazier whites think blacks are, the less they want to spend on welfare. For example, holding all else constant, whites who think blacks are lazy have predicted scores on welfare spending that are 18 units lower (on a 100-unit scale) than whites who think blacks are hardworking.

The relationship between whites' stereotypes of Hispanic work ethic and their welfare-spending preferences, however, is far more ambiguous. Hispanic work ethic is negative and significant at the $5 \%$ level (model 2 of table 2), but loses significance when whites' attitudes about black work ethic are controlled for (model 3). Since whites' attitudes about black and Hispanic work ethic are correlated (.465), it appears that the Hispanic work ethic variable is picking up some of the effect of the black work ethic variable when it is placed in the model alone. Overall, these results 


\section{American Journal of Sociology}

do not offer compelling evidence that whites' stereotypes of Latinos are related to their support for welfare.

\section{THE INFLUENCE OF RACIAL AND ETHNIC CONTEXT}

In this section, I first explore the effect of racial and ethnic context on the prevalence of stereotypes as well as its influence on the impact of stereotypes on welfare -spending preferences in pooled models containing all three years of data. I then examine whether the effect of context changes over time.

\section{The Influence of Context on the Prevalence of Stereotypes}

Table 3 presents a pooled model that estimates how racial and ethnic context is related to whites' beliefs about black and Latino work ethic. Independent variables include year dummies and basic demographic controls including age, sex, marital status, education level, and family income. The dependent variables are black and Latino work ethic stereotypes, measured on a 1-7 scale with high scores for lazy. Models in this article that include contextual variables are estimated using OLS regression with robust standard errors, clustered at the state or county level. ${ }^{21}$

The most striking finding in table 3 is that racial and ethnic context has divergent effects for Latinos and African-Americans. The more blacks in respondents' states, the lazier whites think blacks are. Conversely, the more Latinos in respondents' states, the more hardworking whites think Latinos are. Both of these contextual variables are significant at the $1 \%$ level. $^{22}$ A $10 \%$ increase in the Latino population has roughly the same effect on stereotypes about Latinos as two additional years of education: they both decrease stereotypes about Latinos by about one-tenth of a point (on a seven-point scale). These results hold at the county level as well, but \%black and \%Latino are only significant at the 5\% and $10 \%$ levels, respectively, and the size of the coefficients declines somewhat (models not shown).

These results suggest that the "contact hypothesis" works for Latinos

\footnotetext{
${ }^{21}$ Using robust standard errors allows us to adjust for the fact that the error terms for the contextual variables are correlated, which would tend to produce underestimations of the standard errors for those group-level independent variables.

${ }^{22}$ Since Cubans and Cuban-Americans have generally escaped the "welfare-class stereotype" that other Latino groups have failed to fend off (Cavanagh 2000), it is important to understand whether whites' perceptions of Cubans are driving the result. The NES does not ask respondents about the work ethic for Latinos broken down by country of origin. However, the results are not sensitive to the inclusion or exclusion of Florida, the state with the largest Cuban population.
} 
Changing Color of Welfare

TABLE 3

OLS Predictors of Whites' Work Ethic Stereotypes

\begin{tabular}{|c|c|c|}
\hline \multirow[b]{2}{*}{ VARIABLE } & \multicolumn{2}{|c|}{ STEREOTYPE } \\
\hline & $\begin{array}{l}\text { Latinos } \\
\text { Are Lazy }\end{array}$ & $\begin{array}{l}\text { Blacks } \\
\text { Are Lazy }\end{array}$ \\
\hline 1996 & $\begin{array}{l}-.17 * * * \\
(.04)\end{array}$ & $\begin{array}{l}-.09 * * \\
(.05)\end{array}$ \\
\hline 2000 & $\begin{array}{l}-.28 * * * \\
(.06)\end{array}$ & $\begin{array}{l}-.09 * * \\
(.04)\end{array}$ \\
\hline Age $\ldots \ldots \ldots \ldots \ldots \ldots \ldots \ldots$ & $\begin{array}{l}.000 \\
(.001)\end{array}$ & $\begin{array}{l}.005 * * * \\
(.001)\end{array}$ \\
\hline Female $\ldots \ldots \ldots \ldots \ldots \ldots \ldots$ & $\begin{array}{l}.05 \\
(.04)\end{array}$ & $\begin{array}{l}-.12 * * * \\
(.04)\end{array}$ \\
\hline Married & $\begin{array}{c}-.03 \\
(.04)\end{array}$ & $\begin{array}{l}.07 \\
(.05)\end{array}$ \\
\hline Education in years $\ldots . . .$. & $\begin{array}{l}-.04 * * * \\
(.01)\end{array}$ & $\begin{array}{l}-.05 * * * \\
(.01)\end{array}$ \\
\hline Family income $(\$ 10,000) \ldots$ & $\begin{array}{r}-.007 \\
(.009)\end{array}$ & $\begin{array}{l}.005 \\
(.009)\end{array}$ \\
\hline$\%$ Hispanic in state $\ldots . \ldots .$. & $\begin{array}{l}-.008 * * * \\
(.002)\end{array}$ & $\begin{array}{l}.003 * \\
(.002)\end{array}$ \\
\hline \%black in state $\ldots \ldots \ldots \ldots$ & $\begin{array}{l}-.006 \\
(.004)\end{array}$ & $\begin{array}{l}.013 * * * \\
(.004)\end{array}$ \\
\hline Constant $\ldots \ldots \ldots \ldots \ldots \ldots$ & $\begin{array}{l}4.7 * * * \\
(.21)\end{array}$ & $\begin{array}{l}4.5 * * * \\
(.17)\end{array}$ \\
\hline$R^{2}$ & .0289 & .0325 \\
\hline$N)$ & 3,772 & 3,889 \\
\hline
\end{tabular}

SourCE. - National Election Study 1992, 1996, and 2000.

NotE. - Dependent variables are scored 1-7 with high scores for "lazy." Model includes robust standard errors, clustered at the state level. Numbers in parentheses are SEs.

$* P<.10$.

$* * P<.05$.

$* * * \quad P<.01$.

and not for blacks. The more Latinos in a state or county, the more positive whites feel toward Latinos. Conversely, the more blacks in a state or county, the more negative whites feel toward blacks.

These divergent findings on the influence of racial and ethnic context might be the result of differences in the quality or frequency of contact between whites and Latinos and between whites and African-Americans. Remember that the conditions under which the in-group and out-group meet may determine whether contact will have the expected effect. Lower rates of residential segregation for Latinos (Massey 2000), or a greater propensity to be employed in more visible occupations (service vs. manufacturing, for example), could increase the opportunity for meaningful contact for whites with Latinos relative to African-Americans. Differences 


\section{American Journal of Sociology}

in the historical treatment of blacks and Latinos or their relationship to whites may also account for these results. ${ }^{23}$ This latter interpretation is supported by the fact that the coefficient on age is positive and roughly six times as large in the model where black work ethic is the dependent variable as in the model with Latino work ethic. I interpret this as a cohort rather than an age effect. Older whites are more likely than younger whites to have negative stereotypes of African-Americans but no more likely to have negative stereotypes of Latinos. Differences in welfare utilization rates between blacks and Latinos could also help explain the results. Though blacks and Latinos each make up approximately $12 \%$ of the population, the welfare rolls are $37 \%$ black and only $24 \%$ Latino. This difference in utilization rates may be due at least in part to immigrants' (real and perceived) eligibility for welfare, ${ }^{24}$ or due to differences in employment opportunities for the two groups (Waldinger 2001).

Finally, as an economically motivated immigrant group, Latinos as a whole may appear to exhibit more outward commitment to the work ethic if they have higher rates of participation in the labor force. Overall, according to the 2000 census, Latinos are actually slightly less likely than African Americans to participate in the labor force (67\% vs. 69\%). ${ }^{25}$ These figures obscure significant differences by gender, however. Latino men are more likely than black men to participate in the labor force ( $75 \%$ vs. $69 \%$ ), while the reverse is true among Latina and black women (59\% vs. $70 \%)$. If whites are more concerned about the work ethic of men because of gendered norms about paid work and child care, then real differences in labor force participation between black and Latino men may be driving whites' perceptions about the two groups. However, one should be extremely cautious about inferring real underlying differences in work ethic based on labor force participation or welfare recipiency rates since it is

${ }^{23}$ The psychological literature on stereotypes suggests that, once they are set, stereotypes are resistant to change (Bobo and Massagli 2001). Whites who see blacks or Latinos hard at work may simply discount the evidence as anomalous (Waters 1999). However, greater opportunities for contact with Latinos may provide enough evidence to counteract ingrained stereotypes, or stereotypes about Latinos may not be as firmly set as stereotypes about blacks.

${ }^{24}$ Undocumented immigrants are, of course, ineligible for welfare benefits. Furthermore, many immigrants believe that getting welfare will negatively affect their eligibility for a green card. Under welfare reform, states were granted the right to determine whether immigrants would be eligible for benefits, reducing the rate of welfare utilization among low-income legal immigrant families with children relative to their lowincome citizen counterparts between 1995 and 2000 (Fix and Passel 2002).

${ }^{25}$ All data were calculated using the Census 2000 Summary File 4 (SF 4)-Sample Data. It is possible that the labor force participation rate of Latinos is underestimated because of the significant undocumented Latino population. 


\section{Changing Color of Welfare}

highly problematic to assume that such differences reflect an underlying disposition instead of deep structural constraints.

The Influence of Context on Support for Welfare

The direct effect of racial and ethnic context on support for welfare is more ambiguous. In table 4, I estimate the relationship between racial and ethnic context and support for welfare in a pooled model controlling for year, age, sex, marital status, education, and family income. I exclude controls for party identification, political views, individualism, and work ethic stereotypes because these variables may be partly endogenous to racial and ethnic context. At the state level, \%black and \% Latino are negatively related to welfare-spending preferences, and \%Latino is significant at the $5 \%$ level (model 1 ). The results are insignificant at the county level (results not shown). Therefore, there is support for the proposition that the more Latinos or blacks in a state, the less whites in those states want to spend on welfare.

It is possible, however, that what is driving antiwelfare sentiment in this case is not the ethnic context but the economic context. Latinos and African-Americans have higher poverty and welfare utilization rates than whites. Perhaps whites in states with more Latinos or blacks are more likely to want to decrease spending on welfare not because there are more of either group but because there are more poor people or people on welfare. Controlling for the state poverty level eliminates any relationship between \%Hispanic or \%black and support for welfare (model 2). However, further tests reveal that poor blacks in particular likely trigger antiwelfare sentiment. In model 3 of table 4 I interact \%poor with \%black and \%Latino. The interaction between \%poor and \%black is negative and significant at the $5 \%$ level, suggesting that individuals in states with both higher numbers of African-Americans and a higher poverty rate are more likely to want to decrease spending on welfare.

Given these results for the direct effects of racial and ethnic context, will racial and ethnic context influence whether stereotypes are related to welfare-spending preferences? Table 5 interacts the racial and ethnic context with the stereotype variables and includes all controls. Racial context appears to be unimportant for whether stereotypes about blacks influence support for welfare. Ethnic context, on the other hand, is very important in mediating the relationship between whites' stereotypes about Latinos and their support for welfare. Since the sign is positive, this suggests that the more Latinos, the more likely that whites' stereotypes about Latinos will be positively related to their welfare-spending preferences.

Since interpreting these interactions can be a bit tricky, I will present 
American Journal of Sociology

TABLE 4

OLS Predictors of Whites' Welfare-Spending Preferences: Direct Effect of Racial and Ethnic Context

\begin{tabular}{|c|c|c|c|}
\hline Variable & 1 & 2 & 3 \\
\hline$\%$ black in state...$\ldots \ldots \ldots$ & $\begin{array}{c}-.15 \\
(.14)\end{array}$ & $\begin{array}{c}-.07 \\
(.13)\end{array}$ & $\begin{array}{l}.72 * \\
(.33)\end{array}$ \\
\hline \% Latino in state .......... & $\begin{array}{c}-.13 * \\
(.05)\end{array}$ & $\begin{array}{c}-.01 \\
(.07)\end{array}$ & $\begin{array}{l}.04 \\
(.29)\end{array}$ \\
\hline \%poor in state ............ & $\ldots$ & $\begin{array}{c}-.56^{*} \\
(.22)\end{array}$ & $\begin{array}{l}.17 \\
(.30)\end{array}$ \\
\hline$\%$ poor $\times \%$ black ........ & $\ldots$ & $\ldots$ & $\begin{array}{c}-.06 * \\
(.03)\end{array}$ \\
\hline$\%$ poor $\times \%$ Latino & $\cdots$ & . . & $\begin{array}{c}-.007 \\
(.02)\end{array}$ \\
\hline Constant $\ldots \ldots \ldots \ldots \ldots \ldots$ & $\begin{array}{l}43.9 * * \\
(5.1)\end{array}$ & $\begin{array}{l}49.6 * * \\
(5.0)\end{array}$ & $\begin{array}{l}41.2 * * \\
(6.6)\end{array}$ \\
\hline …… & .0549 & .0570 & .0588 \\
\hline
\end{tabular}

SouRCE. - National Election Study 1992, 1996, and 2000.

NOTE. $-N=4,351$. All models include year dummies as well as controls for age, sex, marital status, education, and family income. Dependent variable is scored 0, 50, 100 for decrease, maintain, and increase welfare spending, respectively. Model includes robust standard errors, clustered at the state level. Numbers in parentheses are SEs.

$* P<.05$.

** $P<.01$.

the same model separated into three types of states: disproportionately Latino states, disproportionately black states, and disproportionately whites states (see fig. 1 for the breakdown of states). ${ }^{26}$ Disproportionately Latino states are states where more than $12 \%$ of the population is Latino. Disproportionately black states are states where more than $12 \%$ of the population is black. And disproportionately white states are states where less than $12 \%$ of the population is black and less than $12 \%$ of the population is Latino. Table $\mathrm{C} 1$ in the appendix provides a demographic breakdown of states included in the study based on 1990 and 2000 census data.

I chose $12 \%$ as a cutoff only because in the 2000 census blacks and Latinos each accounted for roughly $12 \%$ of the national population. Therefore, disproportionately Latino and disproportionately black states would each contain a greater share of Latinos and blacks than the national

\footnotetext{
${ }^{26}$ Separating the country into three separate sections is not equivalent to the model in table 5. Nonetheless, this breakdown is appropriate, I would argue, because it is a theoretically meaningful and parsimonious grouping of states, the division is reasonably close to the model in table 5, and the results do not differ significantly under the two models.
} 


\section{Changing Color of Welfare}

TABLE 5

OlS Predictors of Whites' Welfare-Spending Preferences: Effect of Racial and Ethnic Context on Importance of Stereotypes

\begin{tabular}{|c|c|c|}
\hline \multirow[b]{2}{*}{ VARIABLE } & \multicolumn{2}{|c|}{ MODEL } \\
\hline & Coefficient & SE \\
\hline \%black in state & .32 & .22 \\
\hline 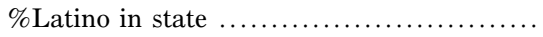 & $-.38 * *$ & .11 \\
\hline 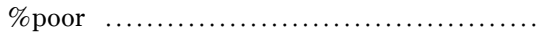 & $-.48 *$ & .22 \\
\hline Believe blacks are lazy $\ldots \ldots \ldots \ldots \ldots \ldots \ldots$ & -10.8 & 7.0 \\
\hline Believe Hispanics are lazy $\ldots \ldots \ldots \ldots \ldots \ldots$ & $-8.5^{*}$ & 3.6 \\
\hline \%black $\times$ believe blacks are lazy $\ldots \ldots \ldots \ldots$ & -.54 & .40 \\
\hline$\%$ Hispanic $\times$ believe Hispanics are lazy $\ldots$ & $.84 * *$ & .16 \\
\hline 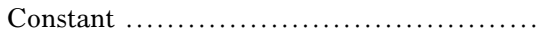 & $74.9 * *$ & 7.3 \\
\hline
\end{tabular}

SourCE. - National Election Study 1992, 1996, and 2000.

Note. $-N=3,053 ; R^{2}=.1778$. The model includes year dummies and controls for age, sex, marital status, education, family income, party identification, political views, and individualism. Dependent variable is scored 0, 50, 100 for decrease, maintain, and increase welfare spending. All political and racial attitude variables are scored $0-1$, with high scores for Republican, conservative, self-reliant/get ahead on own, less government, and lazy. Model includes robust standard errors, clustered at the state level

$* P<.05$.

** $P<.01$

average. The models presented in this article are generally not sensitive to this particular cutoff, however. ${ }^{27}$

A pooled model estimating the relationship between racial and ethnic stereotypes and support for welfare, including all controls and broken down by racial and ethnic context, is presented in table 6. Looking first at the results for disproportionately Latino states, note that the stereotype of Latino work ethic is positive and significant when controlling for whites' views of blacks. There are two ways to interpret the positive coefficient on Latino work ethic. One way in which to think of it is that

${ }^{27}$ In 1990 the fraction of Latinos in the United States was closer to $8 \%$ than it was to $12 \%$. Using $8 \%$ as a cutoff for the 1992 NES data does not significantly alter the results of my model. Similarly, the models presented in this article are not sensitive to the inclusion or exclusion of "borderline" states. For example, I can place Ohio and Missouri, currently designated as disproportionately white states, into the disproportionately black states category (since they are both $11 \%$ black) and the results stay roughly the same. I can also take Michigan, New Jersey, New York, and Florida out of the disproportionately black states section or exclude Illinois, Nevada, and New Jersey from the disproportionately Latino states. Results are simply not sensitive to these changes. This classification scheme is certainly not ideal. For one thing, the labeling is a bit deceiving since there are some states that are labeled disproportionately black that have a higher percentage of whites than some states that fall under the disproportionately white category. For example, Tennessee is $79 \%$ white and labeled a disproportionately black state while Oklahoma is $74 \%$ white and labeled a disproportionately white state. 


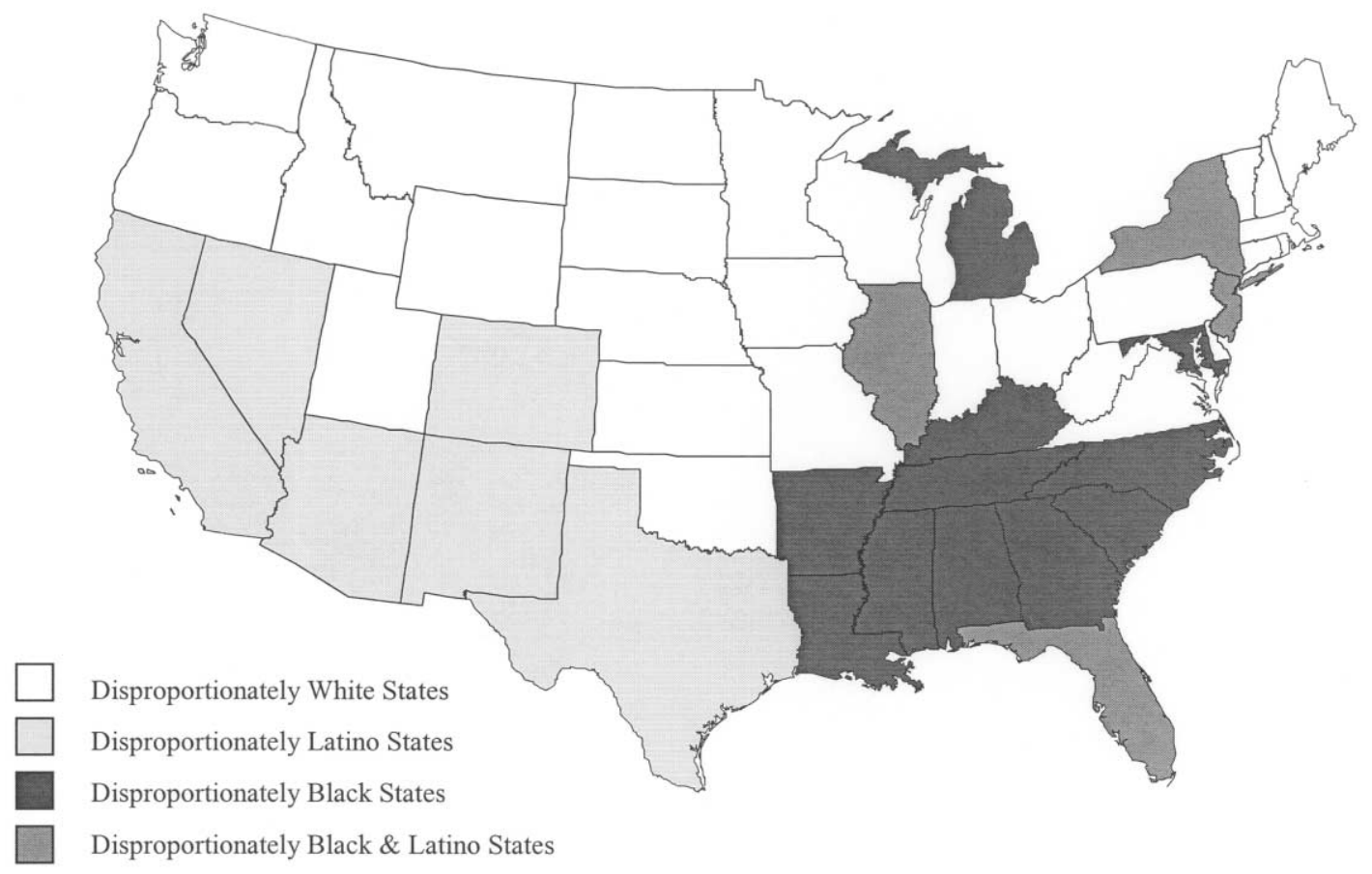

FIG. 1.- The racial and ethnic composition of U.S. states 
TABLE 6

OLS Predictors of Whites' Welfare-Spending Preferences: Effect of Racial and Ethnic Context on Importance of Racial AND ETHNiC STEREOTYPES

\begin{tabular}{|c|c|c|c|c|c|c|c|c|c|}
\hline \multirow[b]{2}{*}{ VARIABLE } & \multicolumn{3}{|c|}{$\begin{array}{c}\text { DiSPROPORTIONATELY LATINO } \\
\text { STATES }\end{array}$} & \multicolumn{3}{|c|}{$\begin{array}{c}\text { DisPROPORTIONATELY WHITE } \\
\text { STATES }\end{array}$} & \multicolumn{3}{|c|}{$\begin{array}{c}\text { DisPRoportionately BLACK } \\
\text { States }\end{array}$} \\
\hline & 1 & 2 & 3 & 1 & 2 & 3 & 1 & 2 & 3 \\
\hline Believe Hispanics are lazy & $\ldots$ & $\begin{array}{c}4.6 \\
(4.9)\end{array}$ & $\begin{array}{l}15.9 * * \\
(5.4)\end{array}$ & $\ldots$ & $\begin{array}{c}-20.9 * * \\
(4.7)\end{array}$ & $\begin{array}{c}-19.7 * * \\
(5.6)\end{array}$ & $\ldots$ & $\begin{array}{r}-5.0 \\
(4.7)\end{array}$ & $\begin{array}{c}6.2 \\
(5.2)\end{array}$ \\
\hline Sample size $(N) \ldots \ldots \ldots \ldots \ldots$ & 997 & 990 & 988 & 1,227 & 1,201 & 1,196 & 1,284 & 1,243 & 1,243 \\
\hline
\end{tabular}

Source - National Election Study 1992,

Note. - All models include year dummies as well as controls for age, sex, marital status, education, family income, political party, political views, individualism, and \%poor. Disproportionately black states also controls for \%Hispanic, and disproportionately Latino states for \% black. Dependent variable is scored $0,50,100$ for decrease, maintain, and increase welfare spending. All political and racial attitude variables are scored $0-1$, with high scores for Republican, conservative, self-reliant/ get ahead on own, less government, and lazy.

$* P<.05$ 
American Journal of Sociology

the lazier whites think Latinos are (controlling for their views about blacks), the more whites want to spend on welfare. It is difficult to tell a convincing story that would support this interpretation, however. The second and more realistic interpretation is the more hardworking whites think Latinos are (controlling for their views about blacks), the less they want to spend on welfare. This latter interpretation makes sense if we think that whites are implicitly comparing the work ethic of Latinos and African-Americans. In disproportionately Latino states, therefore, the more hardworking whites think Latinos are, the less whites want to spend on welfare. The opposite relationship, however, holds for blacks. The lazier whites think blacks are, the less they want to spend on welfare. ${ }^{28}$

In disproportionately white states, the effect of the stereotype about Hispanic work ethic is large, negative, and highly significant. That is, the lazier whites think Latinos are, the less whites want to spend on welfare. Additionally, whites' stereotypes about black work ethic are also negative, but the effect disappears when holding whites' stereotypes about Hispanics constant.

In disproportionately black states, whites' stereotypes of Latino work ethic are negative but insignificant when included alone and positive and insignificant when controlling for black work ethic. The black work ethic variable, however, is large, negative, and significant whether or not one controls for stereotypes about Latinos.

I estimated similar models using county-level racial and ethnic context with the 1992 and 1996 NES (results not shown). The relative size, sign, and significance of the work ethic variables were consistent with the models run using state contextual data. The only noticeable difference was that in disproportionately Latino counties the Latino work ethic variable was not significant, even when controlling for stereotypes about blacks. The sign on the coefficient was still positive, however.

The results in table 6 demonstrate that there is a strong relationship between whites' views of Latinos and their welfare-spending preferences, though the relationship varies considerably depending on the racial and ethnic context of the respondent. It varies so much, in fact, that at a national level (table 2) the divergent effects cancel each other out, making it appear that only a modest relationship exists at best.

In disproportionately Latino states, the more hardworking whites think Latinos are, holding constant their views of blacks, the less they want to spend on welfare. But the lazier whites think blacks are, the less they want to spend on welfare. I propose two explanations for this curious result. First, Latinos in disproportionately Latino states may have become

${ }^{28}$ We could also interpret the black work ethic coefficient as the more hardworking whites think blacks are, the more they want to spend on welfare. 


\section{Changing Color of Welfare}

the "model minority" where work ethic and welfare dependence are assessed relative to blacks. Remember that table 3 showed that whites' stereotypes of Latino work ethic improve with greater exposure to Latinos. If Latinos can do without welfare, the logic likely goes, so can blacks. As a result, whites in these states may be more likely to want to punish blacks for their perceived individual failure to succeed. This interpretation seems reasonable given that whites often point to the successful economic incorporation of European and many Asian immigrants when they blame blacks for their failure to close the socioeconomic gap with whites (Jaynes 2000). If the model minority theory is correct, we would expect that the correlation between stereotypes about blacks and those about Hispanics would be highest in states that are disproportionately white and lowest in states that are disproportionately Latino. This is precisely what we find (.51 in disproportionately white states and .43 in disproportionately Latino states), though the difference is small.

If an implicit comparison between black and Latino work ethic is really at work in disproportionately Latino states, we would expect the least amount of support for welfare from whites who believe that blacks are lazy but Hispanics are not. ${ }^{29}$ This is precisely what I find. In table 7, I divided whites into four categories: whites who believe both blacks and Hispanics are lazy, whites who believe blacks are lazy and Hispanics are not, whites who believe Hispanics are lazy and blacks are not, and whites who think neither blacks nor Hispanics are lazy. I then estimated the same model as in table 6 , with these new variables replacing the simple stereotype variables (omitting the last category-whites who believe that neither Hispanics nor blacks are lazy_-to prevent linear dependence). In disproportionately Latino states the only stereotype driving the results is the variable for whites who think blacks are lazy and Hispanics are not. The implicit comparison of black and Latino work ethic in these states appears to matter most.

An equally plausible alternative interpretation is that whites in disproportionately Latino states are fearful that "hardworking Latinos" are

\footnotetext{
${ }^{29}$ As a reviewer noted, the model minority hypothesis also implies that we should expect the strongest relationship between whites' stereotypes of blacks and white support for welfare among whites in disproportionately Latino states who believe that Hispanics are hardworking, since, according to the reviewer, the "perceived hard work of Latinos is putting 'lazy' African Americans in a worse light." Toward that end, I added an interaction term, "believe blacks are lazy" × "believe Hispanics are lazy," to the model for disproportionately Latino states in table 6 (results not shown). The results were consistent with the model minority hypothesis: the coefficient was large and positive (23.81), suggesting that in disproportionately Latino states, the more hardworking whites think Latinos are, the more whites' stereotypes of blacks as lazy decrease their support for welfare. The standard error was large (18.8), however, and therefore the results were not statistically significant.
} 
TABLE 7

OLS Predictors of Whites' Welfare-Spending Preferences: Effect of Racial and Ethnic Context on IMPORTANCE OF RACIAL AND ETHNiC STEREOTYPES

\begin{tabular}{|c|c|c|c|c|}
\hline & Nationwide & $\begin{array}{l}\text { Disproportionately } \\
\text { Latino States }\end{array}$ & $\begin{array}{l}\text { Disproportionately } \\
\text { White States }\end{array}$ & $\begin{array}{c}\text { Disproportionately } \\
\text { Black States }\end{array}$ \\
\hline Believe blacks and Hispanics are lazy $\ldots \ldots \ldots \ldots$ & $\begin{array}{c}-5.7 * \\
(1.7)\end{array}$ & $\begin{array}{c}-1.4 \\
(2.7)\end{array}$ & $\begin{array}{c}-6.3^{*} \\
(2.4)\end{array}$ & $\begin{array}{c}-7.3^{*} \\
(2.4)\end{array}$ \\
\hline Believe blacks are lazy, Hispanics are not ....... & $\begin{array}{c}-5.2^{*} \\
(1.6)\end{array}$ & $\begin{array}{c}-7.7^{*} \\
(2.7)\end{array}$ & $\begin{array}{l}-3.8 \\
(2.7)\end{array}$ & $\begin{array}{c}-6.3^{*} \\
(2.4)\end{array}$ \\
\hline Believe Hispanics are lazy, blacks are not ....... & $\begin{array}{r}-3.9 \\
(2.7)\end{array}$ & $\begin{array}{l}-4.0 \\
(4.0)\end{array}$ & $\begin{array}{c}-8.4^{*} \\
(3.2)\end{array}$ & $\begin{array}{r}-1.9 \\
(3.5)\end{array}$ \\
\hline Constant & $\begin{array}{c}69.0^{*} \\
(5.3)\end{array}$ & $\begin{array}{c}46.1^{*} \\
(10.3)\end{array}$ & $\begin{array}{c}75.2^{*} \\
(8.3)\end{array}$ & $\begin{array}{c}68.0^{*} \\
(8.6)\end{array}$ \\
\hline Adjusted $R^{2}$ & .1696 & .1653 & .1844 & .1492 \\
\hline$N \ldots \ldots \ldots \ldots$ & 3,219 & 1,023 & 1,274 & 1,312 \\
\hline
\end{tabular}

SOURCE. - National Election Study 1992, 1996, and 2000.

NoTE. - All models include year dummies as well as controls for age, sex, marital status, education, family income, political party, political views, individualism, and \%poor. Disproportionately black states also controls for \%Hispanic, and disproportionately Latino states for \%black. Dependent variable is scored 0, 50, 100 for decrease, maintain, and increase welfare spending. All political variables are scored $0-1$, with high scores for Republican SEs.

* $P<.01$. 


\section{Changing Color of Welfare}

being seduced by the perverse incentives of welfare and becoming dependent and lazy just as they believe blacks have. This interpretation could help reconcile the positive coefficient for Latino work ethic with the high proportion of Latino welfare recipients in these states. In California, Texas, and New Mexico, for example, while both Latinos and blacks are disproportionately represented in the ranks of those on welfare, Latinos far outnumber blacks because of their greater presence in those states. ${ }^{30}$ Indeed Sanchez (1997) argues that Latino (and Asian) immigrants may be replacing or at least joining poor blacks as the scapegoat of choice for America's social and economic ills (see also Calavita 1996; Mehan 1997). This interpretation might also help explain widespread white support in the early 1990s for Proposition 187 in California, which sought to ban undocumented immigrants from access to social services, including welfare, nonemergency health services, and public education, an exclusion that was generally regarded as targeting Latinos (see Fujiwara 1999).

Adjudicating between these two competing explanations would be possible if one were able to determine the causal relationship between racial and ethnic stereotypes and support for welfare-that is, if one could determine whether whites' stereotypes about Latinos or blacks influence their support for welfare (as I had originally assumed following Gilens) or whether antiwelfare sentiment is driven by the belief that welfare makes groups lazy because of its perverse incentive structure. Though I suspect that both are true, future research is needed in order to determine which account provides the most compelling explanation.

In stark contrast to whites in disproportionately Latino areas, whites who live in disproportionately white states or counties see Latinos in a manner that is more consistent with how whites generally see blacks. The lazier whites think Latinos are, the less they want to spend on welfare. Similarly the lazier whites think blacks are, the less they want to spend on welfare, though the effect disappears when whites' stereotypes of Latinos are controlled for. Since whites' stereotypes of black and Latino work ethic are highly correlated (especially in disproportionately white states), it is possible that when placed in the model alone, black work

${ }^{30}$ In California in $1998,41 \%$ of TANF families were Hispanic while only $22 \%$ were black. In New Mexico, 55\% of TANF families were Hispanic while only 3.5\% were black. And in Texas, $50 \%$ of TANF families were Hispanic compared to $31 \%$ black. Data are for the 1998 fiscal year and from the National Emergency TANF Datafile as of May 28, 1999. Unfortunately, it is not possible to test this hypothesis directly. The racial and ethnic composition of the welfare rolls is highly correlated to the racial and ethnic composition of the state (.85). When these variables are placed in the model simultaneously, there is evidence of multicolinearity. The results in this article are generally similar, though somewhat weaker, when the racial and ethnic composition of the welfare rolls is used instead of the racial and ethnic composition of the state. 
American Journal of Sociology

ethic is actually picking up the effect of Latino work ethic. Alternatively, it could be that both variables are important to understand antiwelfare sentiment. Theoretically, it is far more plausible that both variables are important given prior research in the area as well as the literature on media representations of the poor discussed below.

Why does the relationship between stereotypes about Latinos and support for welfare differ so much based on ethnic context? In table 3, we found that whites in high Latino areas were more likely to think that Latinos were hardworking. Proximity in this case breeds amity. Whites in disproportionately white states have less contact with Latinos, and as a result they are more dependent on media images to form opinions about Latinos' work ethic and their relationship to the welfare system. During the early to mid 1990s, there was a considerable amount of anti-immigrant sentiment across the country-much of it directed against Latinos. There was also a specific concern that the welfare system had become somewhat of a magnet for immigrants, resulting in a sharp increase in the number of immigrants on welfare (Borjas 1999; Sanchez 1997). For example, former presidential candidate Pat Buchanan proposed that the United States build a wall along the Mexican border to keep the alleged welfare abusers out (Herrick 1996). Pat Buchanan may fall at one extreme, but polls generally showed that many Americans were reluctant to extend welfare benefits to legal immigrants (Shaw and Shapiro 2002). While NES questions about stereotypes prompt respondents to offer their opinions on the work ethic of Hispanic-Americans-not Hispanic immigrants-it is possible that apprehensions about immigration and migration still come into play (see Fujiwara 1999). Perhaps as a result, whites in predominantly white states are slightly more likely than whites in other states to believe that Latinos are lazier than blacks (18\% vs. $15.5 \%)$ and less likely to believe that blacks are lazier than Latinos (27\% vs. $35 \%$ ).

In contrast to our findings about the effect of ethnic context on the influence of stereotypes about Latinos on support for welfare, whites' stereotypes of blacks are related to their welfare-spending preferences, largely irrespective of racial and ethnic context. The interaction between \%black and black work ethic is insignificant in table 5, and in table 6 whites' stereotypes of blacks in disproportionately black, Latino, or white states are always negative. Why might this be the case? While Gilens (1999) does not test the effect of racial and ethnic context in his models, his work still suggests that racial context may not matter much at all. It is due to biased media representations, he argues, that whites in states with few blacks are just as likely to have distorted perceptions about the fraction of the poor that is black nationally as whites in states with many 


\section{Changing Color of Welfare}

African-Americans. ${ }^{31}$ Since most decisions about welfare aside from welfare benefit levels were made at the national level prior to 1996 (the period Gilens studies), neighborhood, county, or state context may not affect whether racial and ethnic stereotypes are linked to support for federal welfare spending. Everybody "knows" that welfare is a program for blacks, Gilens's logic presumes, therefore everyone will let their stereotypes about blacks influence their support for the program.

What about Latinos? Gilens failed to consider Latinos in his analysis, but Clawson and Trice (2000) have done so. They analyzed media portrayals of the poor from 1993 through 1998 in five national news magazines. They found 74 stories with 149 pictures of 357 poor people. Of those, the authors judged $49 \%$ to be black, $33 \%$ white, $19 \%$ Latino, and none Asian. These figures overrepresent the percentage of the poor who are black while they greatly underestimate the percentage of the poor who are white and Asian and slightly underrepresent the percentage of the poor who are Latino (see fig. 2). Even if we compare the media representation of the poor with the racial and ethnic composition of the welfare rolls (Lower-Basch 2000), we find that media pictures still overstate the extent of black poverty and welfare usage. Furthermore, the authors found that in stories with unsympathetic portrayals of poor people, the media distortion was even greater for blacks and whites but not Latinos: $63 \%$ of the undeserving poor were black, while $19 \%$ were white and $18 \%$ were Latino. So while African-Americans are only slightly more likely than Latinos to be poor, they are two and a half times as likely to be depicted as poor by the media and more than four times as likely to be depicted as poor when the stories are unsympathetic.

Combined with the findings on the effect of context on the prevalence of stereotypes, these findings may explain then why racial and ethnic context is more important for the political impact of whites' stereotypes of Latinos than for their stereotypes of blacks. If media images of AfricanAmericans are predominantly negative and having more blacks in a state does nothing to counter those views-in fact, if anything it reinforces them - then context should not matter much for whites' thoughts about African-Americans and welfare. On the other hand, if negative media images about Latinos and welfare are less prevalent and having more Latinos in a state makes whites feel more positive toward them, then it is reasonable that effects will depend on the ethnic context.

\footnotetext{
${ }^{31}$ There exists an extensive literature on the influence the media or political elites have on attitudes about race (Gilliam and Iyengar 2000; Valentino, Hutchings, and White 2002), racial inequality (Iyengar 1991), poverty (Gilens 1996a; Iyengar 1990, 1991), as well as attitudes toward welfare and other programs for the poor (Mendelberg 2001; Nelson and Kinder 1996).
} 


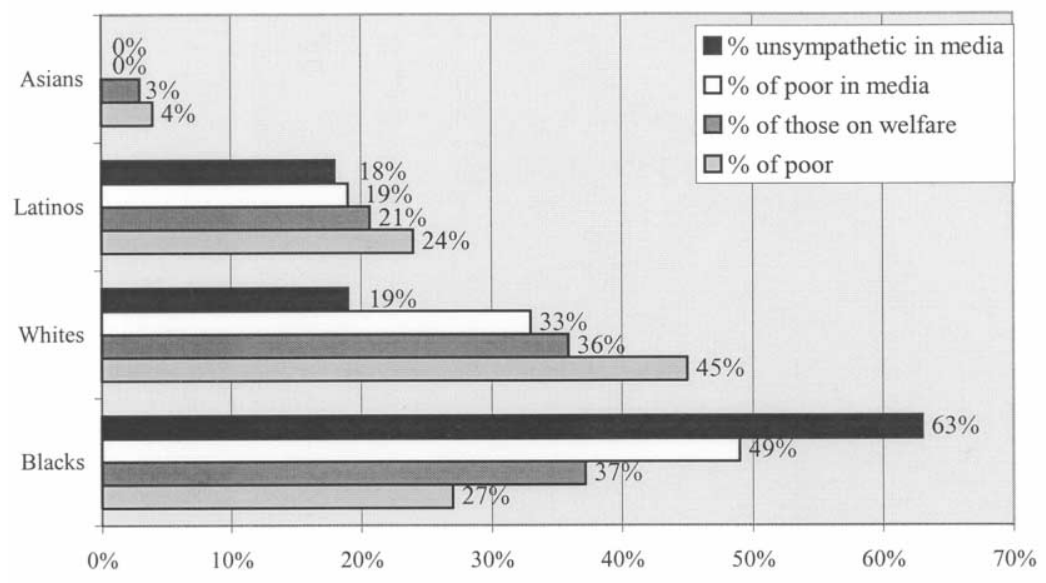

FIG. 2.-Media representations of the poor (data are from Clawson and Trice [2000] and Lower-Basch [2000]).

Given that whites are more likely to see blacks depicted unfavorably in the national media, it is curious that the coefficient on the Latino work ethic variable is larger than the coefficient on the black work ethic variable in disproportionately white states. I can only speculate about why this might be the case. If images of Latinos or discussions about Latinos migrating for high welfare benefits were new to whites in those states, they might be more alarmed or threatened by those messages, even if they were less frequent.

Does the Effect of Racial and Ethnic Context Vary over Time?

Many important changes occurred between 1992 and 2000. President William Jefferson Clinton signed the Personal Responsibility and Work Opportunity Reconciliation Act into law in August of 1996. In addition to ending the entitlement to welfare and barring most legal immigrants from access to benefits, the federal government replaced matching state spending for cash assistance with fixed block grants and gave state legislatures greater discretion to set their own eligibility standards, benefit levels, and program rules. Furthermore, the country witnessed an explosion in the Latino population with the fastest growth occurring in the south, midwest, and northwest. ${ }^{32}$ How might these important changes affect our results about racial and ethnic context? Separate models for each year, grouped

\footnotetext{
${ }^{32}$ Rates of growth were unarguably highest in these areas because the Latino population in these areas was so small to begin with.
} 


\section{Changing Color of Welfare}

by racial and ethnic state level context are presented in tables 8,9 , and 10 in order to understand whether the results we found in table 6 vary over the eight-year time period.

Table 8 shows the results for disproportionately Latino states across all three years. No obvious patterns emerge. The lazier whites think blacks are, the less they want to spend on welfare. Conversely, the more hardworking whites think Latinos are, the less they want to spend on welfare. This general pattern holds across all three survey years, though the effect is strongest in 1992 .

Similarly, there are no consistent patterns in disproportionately black states (see table 9). None of the coefficients for whites' stereotypes of Latino work ethic are particularly large, and none are even weakly significant. In the models that control for black work ethic, the sign on the Latino work ethic variable changes from positive to negative with no particularly obvious trend. Like the racial and ethnic stereotypes in other states, the size of the coefficient for black work ethic drops a bit in 1996. It is still significant at the 5\% level when not controlling for Latino work ethic but then loses significance when that additional control is added.

In disproportionately white states, however, there is one obvious change (see table 10). The pattern in the pooled model (the lazier whites think Latinos or blacks are, the less they want to spend on welfare) only applies to 1992 and 1996. In 2000, neither whites' stereotypes of blacks nor their stereotypes of Latinos are related to whites' welfare-spending preferences. ${ }^{33}$

Given that the size of the coefficient on Latino and black work ethic decreases across all three years, it may be tempting to interpret this as a gradual decrease in the relationship between whites' stereotypes and their welfare-spending preferences. Looking at the trends in disproportionately black and Latino states, though, we see that the effect of stereotypes decreased uniformly in 1996, the year antiwelfare sentiment was at its height, and then returns to pre-welfare reform levels by 2000. Since there is no reason to expect differences in the effect of context over time between disproportionately white states and disproportionately black and Latino states, the finding in 2000 is all the more remarkable.

Why, then, does the relationship between whites' support for welfare and their stereotypes of both blacks and Hispanics in disproportionately

${ }^{33}$ The decrease in the effect of stereotypes about Hispanics is significant (at the $1 \%$ level for the change between 1992 and 2000 and at the 10\% level for the change between 1996 and 2000). The decrease in the effect of stereotypes about blacks (when included in the model alone) between 1992 and 2000 is significant at the $10 \%$ level. 
TABLE 8

OLS Predictors of Whites' Welfare-Spending Preferences, Disproportionately Latino States

\begin{tabular}{|c|c|c|c|c|c|c|c|c|c|}
\hline \multirow{2}{*}{ VARIABLE } & \multicolumn{3}{|c|}{1992} & \multicolumn{3}{|c|}{1996} & \multicolumn{3}{|c|}{2000} \\
\hline & 1 & 2 & 3 & 1 & 2 & 3 & 1 & 2 & 3 \\
\hline Believe blacks are lazy & $\begin{array}{c}-19.3^{* *} \\
(9.1)\end{array}$ & $\cdots$ & $\begin{array}{c}-31.1 * * * \\
(10.4)\end{array}$ & $\begin{array}{c}-14.9^{*} \\
(8.8)\end{array}$ & $\ldots$ & $\begin{array}{c}-21.2^{* *} \\
(9.6)\end{array}$ & $\begin{array}{c}-24.6^{* *} \\
(9.7)\end{array}$ & $\cdots$ & $\begin{array}{l}-32.8^{* * *} \\
(10.8)\end{array}$ \\
\hline Believe Hispanics are lazy & 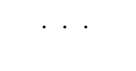 & $\begin{array}{c}7.9 \\
(8.5)\end{array}$ & $\begin{array}{l}20.6 * * \\
(9.5)\end{array}$ & $\ldots$ & $\begin{array}{c}6.0 \\
(8.2)\end{array}$ & $\begin{array}{c}14.1 \\
(9.0)\end{array}$ & $\ldots$ & $\begin{array}{l}2.7 \\
(8.8)\end{array}$ & $\begin{array}{c}16.1 * \\
(9.7)\end{array}$ \\
\hline Constant . & $\begin{array}{l}59.8 \text { *** } \\
(18.0)\end{array}$ & $\begin{array}{l}40.0 * * \\
(18.2)\end{array}$ & $\begin{array}{l}51.6 * * * \\
(18.4)\end{array}$ & $\begin{array}{l}50.8^{* * * *} \\
(16.3)\end{array}$ & $\begin{array}{l}39.3 * * \\
(16.3)\end{array}$ & $\begin{array}{l}46.3^{* * * *} \\
(16.5)\end{array}$ & $\begin{array}{c}29.2 \\
(20.3)\end{array}$ & $\begin{array}{l}11.9 \\
(20.3)\end{array}$ & $\begin{array}{c}22.6 \\
(20.4)\end{array}$ \\
\hline $\begin{array}{l}\text { Adjusted } R^{2} \ldots \ldots \ldots \ldots \\
N \quad \ldots \ldots\end{array}$ & $\begin{array}{c}.1327 \\
362\end{array}$ & $\begin{array}{c}.1197 \\
357\end{array}$ & $\begin{array}{c}.1424 \\
356\end{array}$ & $\begin{array}{c}.1964 \\
315\end{array}$ & $\begin{array}{c}.1885 \\
315\end{array}$ & $\begin{array}{c}.1976 \\
314\end{array}$ & $\begin{array}{c}.0594 \\
320\end{array}$ & $\begin{array}{c}.0427 \\
318\end{array}$ & $\begin{array}{c}.0679 \\
318\end{array}$ \\
\hline
\end{tabular}

SourcE. - National Election Study 1992, 1996, and 2000

NoTE.-All models include year dummies as well as controls for age, sex, marital status, education, self-interest, political party, political views, individualism, and \%poor. Disproportionately black states also controls for \%Hispanic, and disproportionately Latino states for \%black. Dependent variable is scored 0, 50, 100 for decrease, maintain, and increase welfare spending. All political and racial attitude variables are scored 0-1, with high scores for Republican, conservative, self-reliant, less government, and lazy. Numbers in parentheses are SEs.

$* P<.10$.
$* * \quad P<.05$

*** $P<.01$. 
TABLE 9

OlS Predictors of Whites' Welfare-Spending Preferences, Disproportionately Black States

\begin{tabular}{|c|c|c|c|c|c|c|c|c|c|}
\hline \multirow[b]{2}{*}{ VARIABLE } & \multicolumn{3}{|c|}{1992} & \multicolumn{3}{|c|}{1996} & \multicolumn{3}{|c|}{2000} \\
\hline & 1 & 2 & 3 & 1 & 2 & 3 & 1 & 2 & 3 \\
\hline Believe blacks are lazy .... & $\begin{array}{c}-29.2 * * * \\
(8.1)\end{array}$ & . . & $\begin{array}{c}-32.4 * * * \\
(9.9)\end{array}$ & $\begin{array}{c}-16.3^{* *} \\
(8.0)\end{array}$ & & $\begin{array}{r}-14.4 \\
\quad(9.3)\end{array}$ & $\begin{array}{c}-22.4^{* * * *} \\
(8.0)\end{array}$ & $\cdots$ & $\begin{array}{c}-26.5 * * * \\
(8.8)\end{array}$ \\
\hline Believe Hispanics are lazy & $\ldots$ & $\begin{array}{r}-10.0 \\
(8.2)\end{array}$ & $\begin{array}{c}6.1 \\
(9.5)\end{array}$ & $\cdots$ & $\begin{array}{c}-8.4 \\
(8.3)\end{array}$ & $\begin{array}{c}-1.6 \\
(9.4)\end{array}$ & $\ldots$ & $\begin{array}{c}2.7 \\
(7.8)\end{array}$ & $\begin{array}{l}13.3 \\
(8.5)\end{array}$ \\
\hline Constant & $\begin{array}{l}110.5 * * * \\
(15.0)\end{array}$ & $\begin{array}{l}104.7 * * * \\
(15.8)\end{array}$ & $\begin{array}{l}113.1^{* * *} \\
(15.9)\end{array}$ & $\begin{array}{l}85.6 * * * \\
(14.5)\end{array}$ & $\begin{array}{l}79.7 * * * \\
(14.8)\end{array}$ & $\begin{array}{l}83.7 * * * \\
(15.0)\end{array}$ & $\begin{array}{l}40.2 * * \\
(14.8)\end{array}$ & $\begin{array}{c}22.6 \\
(14.9)\end{array}$ & $\begin{array}{c}32.5^{*} \\
(15.1)\end{array}$ \\
\hline Adjusted $R^{2} \ldots \ldots \ldots \ldots \ldots \ldots \ldots \ldots \ldots \ldots \ldots \ldots \ldots$ & .1662 & .1556 & .1737 & .2075 & .2070 & .2101 & .1053 & .0981 & .1156 \\
\hline$N$ & 484 & 458 & 458 & 373 & 365 & 365 & 427 & 420 & 420 \\
\hline
\end{tabular}

SOURCE. - National Election Study 1992, 1996, and 2000.

NoTE.-All models include year dummies as well as controls for age, sex, marital status, education, self-interest, political party, political views, individualism, and \%poor. Disproportionately black states also controls for \%Hispanic, and disproportionately Latino states for \%black. Dependent variable is scored 0,50 , 100 for decrease, maintain, and increase welfare spending. All political and racial attitude variables are scored $0-1$, with high scores for Republican, conservative, self-reliant, less government, and lazy. Numbers in parentheses are SEs.

$* P<.10$.

** $P<.05$

*** $P<.01$. 
TABLE 10

OlS Predictors of Whites' Welfare-Spending Preferences, Disproportionately White States

\begin{tabular}{|c|c|c|c|c|c|c|c|c|c|}
\hline \multirow[b]{2}{*}{ VARIABLE } & \multicolumn{3}{|c|}{1992} & \multicolumn{3}{|c|}{1996} & \multicolumn{3}{|c|}{2000} \\
\hline & 1 & 2 & 3 & 1 & 2 & 3 & 1 & 2 & 3 \\
\hline Believe blacks are lazy $\ldots \ldots \ldots$ & $\begin{array}{c}-22.6^{* * * *} \\
(8.0)\end{array}$ & $\cdots$ & $\begin{array}{l}-.28 \\
(9.4)\end{array}$ & $\begin{array}{r}-14.1^{*} \\
(8.0)\end{array}$ & $\cdots$ & $\begin{array}{r}.87 \\
(10.0)\end{array}$ & $\begin{array}{c}-2.3 \\
(9.0)\end{array}$ & $\ldots$ & $\begin{array}{l}-5.5 \\
(10.5)\end{array}$ \\
\hline Believe Hispanics are lazy & $\ldots$ & $\begin{array}{c}-40.4^{* * * *} \\
(7.9)\end{array}$ & $\begin{array}{c}-40.8 * * * \\
(9.4)\end{array}$ & $\ldots$ & $\begin{array}{c}-25.9 * * * \\
(8.5)\end{array}$ & $\begin{array}{c}-25.2 * * \\
(10.7)\end{array}$ & $\ldots$ & $\begin{array}{c}1.5 \\
(8.2)\end{array}$ & $\begin{array}{c}3.1 \\
(9.5)\end{array}$ \\
\hline Constant & $\begin{array}{l}80.8^{* * * *} \\
(13.9)\end{array}$ & $\begin{array}{l}93.7 * * * \\
(14.1)\end{array}$ & $\begin{array}{l}93.9 * * * \\
(14.2)\end{array}$ & $\begin{array}{l}70.6^{* * * *} \\
(14.8)\end{array}$ & $\begin{array}{l}74.9 * * * \\
(15.0)\end{array}$ & $\begin{array}{l}73.9 * * * \\
(15.1)\end{array}$ & $\begin{array}{l}76.0^{* * * *} \\
(16.2)\end{array}$ & $\begin{array}{l}78.7 * * * \\
(16.4)\end{array}$ & $\begin{array}{l}81.1^{* * *} \\
(16.7)\end{array}$ \\
\hline Adjusted $R^{2} \ldots$ & .1369 & .1745 & .1717 & .2061 & .2264 & .2169 & .1158 & .1221 & .1230 \\
\hline Sample size $(N) \ldots \ldots \ldots$ & 478 & 463 & 461 & 343 & 338 & 337 & 406 & 400 & 398 \\
\hline
\end{tabular}

SOURCE. - National Election Study, 1992, 1996, and 2000.

NoTE. - All models include year dummies as well as controls for age, sex, marital status, education, self-interest, political party, political views, individualism, and \%poor. Disproportionately black states also controls for \%Hispanic, and disproportionately Latino states for \%black. Dependent variable is scored 0 , 50, 100 for decrease, maintain, and increase welfare spending. All political and racial attitude variables are scored 0-1, with high scores for Republican, conservative, self-reliant, less government, and lazy. Numbers in parentheses are SEs.

$* P<.10$.

*** $P<.01$ 


\section{Changing Color of Welfare}

white states mysteriously disappear in $2000 ?^{34}$ A good explanation for this curious result must explain why the coefficient on both black and Hispanic work ethic nears zero. I offer a tentative explanation for this finding that relates to the changes that welfare reform brought to the relationship between the federal and state governments. Welfare reform devolved much of the responsibility for setting welfare policy to the states. To be sure, TANF is still funded in part through federal money. However, prior to 1996 federal money to states came in direct proportion to the welfare caseload size: an increase in the number of people on welfare led to an increase in federal dollars. So did an increase in benefits. Since welfare reform, the federal government gives each state welfare funds in the form of block grants-fixed under law to 1996 caseload levels-for states to spend, along with their own funds, as they see fit. With federal dollars essentially fixed, any increases or decreases in welfare spending come out of state funds and will affect only the welfare recipients in their state. Furthermore, states were given considerable leeway in designing the dayto-day operation of the program, including discretion over state time limits, sanctions, and incentives to encourage recipients to leave welfare. Therefore, asking whites whether they want to increase or decrease spending on welfare can mean very different things depending on when the question is asked. This move toward greater state discretion may mean that whites' stereotypes of blacks and Hispanics in say, Maine, are less relevant to their preferences about welfare spending in 2000 because voters in Maine now have more control over how that money affects poor residents of Maine, and poor residents of Maine are almost exclusively white.

How cognizant the average person is about these changes in the welfare system is a serious question. However, people do not have to be aware of the details surrounding the administration of welfare for this theory to hold water. Previous research suggests that politicians conjoin issues of welfare and race in order to gain (white) votes by capitalizing on whites' underlying fears and frustrations (Edsall and Edsall 1992; Mendelberg 2001; Quadagno 1994). Experimental studies show that whites' racial attitudes can be primed by news stories or campaign advertisements about welfare that contain implicit racial appeals (Mendelberg 2001). Implicit appeals do not actually mention race, but they are often accompanied by pictures of black or brown women or conjure up images of the urban

\footnotetext{
${ }^{34}$ This result is so dramatic that it begs for a technical or methodological explanation. Perhaps the NES was administered differently in 2000. This technical explanation is unsatisfying. If the change were related to survey administration, we would expect that it would affect disproportionately Latino or black states in the same manner as disproportionately white states. We see no evidence of this.
} 
American Journal of Sociology

underclass. In one such appeal in 1994, the Republican Party in California sent voters a brochure they titled "The Welfare Mess." A picture of food stamps, a gun, and drug paraphernalia adorned the cover, and the text inside cautioned the readers, "If You Don't Vote, THEY WIN" (as quoted in Brown 1999, p. 357). If local politicians are aware of the changes brought about by welfare reform and alter their political appeals, the link between whites' stereotypes and welfare-spending preferences could be severed. ${ }^{35}$

If changes in the administration of welfare are responsible for these curious results, then even though the link between welfare and stereotypes was severed, we would not expect the prevalence of stereotypes about blacks and Latinos to be significantly different in disproportionately white states than in more diverse contexts. While whites in disproportionately white states are least likely to think blacks are lazy, they are also least likely to think Latinos are hardworking (see table 11). I also tested whether there was a context-specific decline in whites' stereotypes of blacks or Latinos during these three years and found none (results not shown). Whites in disproportionately white states did not suddenly become less prejudiced relative to whites in other, more diverse states, supporting the theory of political contexts above.

Furthermore, we might expect that, if the link between race and welfare was severed because of administrative changes, more diverse states would be more likely than racially homogeneous states to adopt punitive welfare policies in the wake of welfare reform. If whites (politicians and public alike) oppose welfare because they think the benefits go to blacks and Latinos who are lazy and therefore undeserving, then support for more liberal policies should increase when the benefits are seen to go to whites. Soss et al. (2001) have found that this is the case. Holding constant various social, political, and economic factors, states with a higher proportion of blacks on the welfare rolls had stricter time limits, harsher sanctions, lower state welfare benefit levels, and were more likely to enact family cap policies than states with small proportions of blacks. Similarly, states with a higher proportion of Latinos on the welfare rolls were more likely to have stricter time limits and to adopt a family cap provision (see also Gais and Weaver 2002). The increase in state discretion and changes in the funding of welfare therefore provide a plausible, if not entirely satisfying, explanation for the time- and context-specific disappearance of

\footnotetext{
${ }^{35}$ The NES is administered in the nine weeks immediately preceding the November general election and again in the weeks immediately following the election. In order for this explanation to be convincing, one would have to believe that politicians did not alter their political appeals immediately after the passage of PRWORA in August 1996 since these findings do not appear in the 1996 data.
} 
Changing Color of Welfare

TABLE 11

Frequencies of Whites' Racial and Ethnic Stereotypes, by Racial and Ethnic CONTEXT, 2000

\begin{tabular}{|c|c|c|c|}
\hline Beliefs about Work Ethic & $\begin{array}{c}\text { Disproportionately } \\
\text { Black States }\end{array}$ & $\begin{array}{l}\text { Disproportionately } \\
\text { Latino States }\end{array}$ & $\begin{array}{l}\text { Disproportionately } \\
\text { White States }\end{array}$ \\
\hline \multicolumn{4}{|l|}{ Of blacks: } \\
\hline Lazy $(\%) \quad \ldots \ldots \ldots \ldots \ldots$ & 32 & 32 & 27 \\
\hline Hardworking $(\%) \quad \ldots \ldots \ldots$ & 25 & 26 & 23 \\
\hline \multicolumn{4}{|l|}{ Of Latinos: } \\
\hline Lazy $(\%) \quad \ldots \ldots \ldots \ldots \ldots$ & 18 & 20 & 19 \\
\hline Hardworking $(\%) \ldots \ldots$. & 41 & 45 & 37 \\
\hline \multicolumn{4}{|l|}{ Of whites: } \\
\hline Lazy $(\%) \quad \ldots \ldots \ldots \ldots \ldots$ & 6 & 7 & 6 \\
\hline Hardworking $(\%) \quad \ldots \ldots \ldots$ & 56 & 59 & 59 \\
\hline
\end{tabular}

SouRCE.-National Election Study 2000.

the link between whites' stereotypes of blacks and Latinos and their support for welfare.

\section{CONCLUSIONS}

Most of the theorizing and empirical work on race and welfare to date have relied on a black-white paradigm of race relations. That research has been invaluable in demonstrating the complex relationship between whites' views of blacks and their preferences for various redistributive policies. But as the share of the Latino population rises-both in the country and within the ranks of the poor and those on welfare-researchers cannot continue to ignore how whites' views of Latinos come into play.

A key finding in this study is that whites' stereotypes of Latinos are related to their welfare policy preferences. In order to clearly understand this relationship, however, one needs to consider the racial and ethnic context in which the respondent lives. Ethnic context is important because it has a direct effect on the prevalence of stereotypes. The contact hypothesis "works" for Latinos: the more Latinos in white respondents' state or county, the more hardworking whites think Latinos are. Ethnic context is also important because it has a strong effect on the relationship between stereotypes and support for welfare. In areas with more Latinos, the more hardworking whites think Latinos are (holding constant their stereotypes of blacks), the less they want to spend on welfare. Conversely, the lazier whites think blacks are, the less they want to spend on welfare. Determining why we see such divergent effects in states with more Latinos is beyond the scope of this study. I offered two tentative explanations. First, 


\section{American Journal of Sociology}

whites in states with more Latinos may be holding Latinos as the model minority against which they judge blacks. Since Latinos can make it without welfare, so the logic goes, so can blacks, and therefore spending on welfare should be decreased. Alternatively, whites may fear that Latinos will follow what they see as the path of blacks and become lazy if the welfare system is allowed to grow too large.

This study also found that when whites are racially and ethnically isolated, Latinos appear to be seen as more similar to blacks. In fact, in the early 1990s Latinos had perhaps become the special target of whites' animosity. In disproportionately white states, the lazier whites thought Latinos were, the less they wanted to spend on welfare. Similarly, the lazier whites thought blacks were, the less they wanted to spend on welfare, though that relationship disappeared when controlling for views of Latinos.

Consistent with previous research, I found that stereotypes about black work ethic still fuel antiwelfare sentiment in most states, and this relationship appears to be less responsive to racial and ethnic context than the relationship between stereotypes of Latinos and support for welfare. Context certainly matters for the prevalence of stereotypes about blacks. Unlike our findings for Latinos, the contact hypothesis does not work for African-Americans: the more blacks in respondents' state or county, the lazier whites think blacks are. Context was less important in mediating the relationship between stereotypes about blacks and support for welfare in the early and mid 1990s, most likely because of pervasive misrepresentations of blacks in the national media. When state racial and ethnic context became important after 1996, the results were consistent with the threat hypothesis.

One highly unexpected result in this study was that stereotypes about both blacks and Latinos became suddenly irrelevant to the welfare-spending preferences of whites in disproportionately white states in the 2000 data. I speculated that changes brought about by welfare reform-mainly the use of block grants and increased state control over the design of state welfare plans-may have severed the relationship between whites' stereotypes of blacks and Latinos and their welfare-spending preferences in those states. This argument seems plausible since the prevalence of racial and ethnic stereotypes were not uniformly lower among whites in racially isolated states than among whites in more diverse contexts. Local politicians in racially isolated states, more attuned to the implications of welfare reform than the general public, may have stopped wielding race and welfare as a political and cultural weapon designed to gain votes from anxious whites. This hypothesis is obviously speculative, and future research should examine this possibility. If the hypothesis is accurate, however, these findings suggest that we should be wary of giving states 


\section{Changing Color of Welfare}

too much discretion over welfare. As long as racial and ethnic stereotypes continue to play a role in whites' support of welfare in the rest of the country, giving states this discretion only provides additional avenues in which prejudice is allowed to influence policy choices. We could see additional moves toward two unequal welfare systems: a more generous system in the disproportionately white north and a miserly version in the south and southwest.

Overall this study concludes that numbers sometimes count, but not always in the way that the threat hypothesis predicts. For blacks, when they count, greater numbers mean increasing stereotypes and decreasing support for racially tinged policies, including welfare, among whites. Numbers are not important for the relationship between stereotypes and support for welfare when decisions about welfare are made at the national level. For Latinos, greater numbers can mean greater amity-not greater animosity - toward the group, at least where stereotypes about work ethic are concerned. But that greater amity does not translate into greater support for welfare, a program that many Latinos clearly rely on. Whether antiwelfare sentiment in that context should be understood to be directed against blacks (the Latinos as model minority hypothesis) or against both blacks and Latinos (the hypothesis that welfare might make Latinos lazy) is important to determine, if only because it tells us something about how Latinos are being, and will continue to be, incorporated into the American racial order. Will Latinos become "honorary whites" whose interests will be pitted against the interests of African-Americans? Or will Latinos occupy some middle rung on the racial hierarchy—not quite honorary white, not quite degraded black? However we answer these questions, for the time being at least, one result remains: whites' stereotypes about blacks and Latinos - whether negative or positive-decrease support for policies that are intended to assist all of the nations' poor. 


\section{APPENDIX A}

TABLE A1

Survey Questions for 1992, 1996, AND 2000 National Election Study

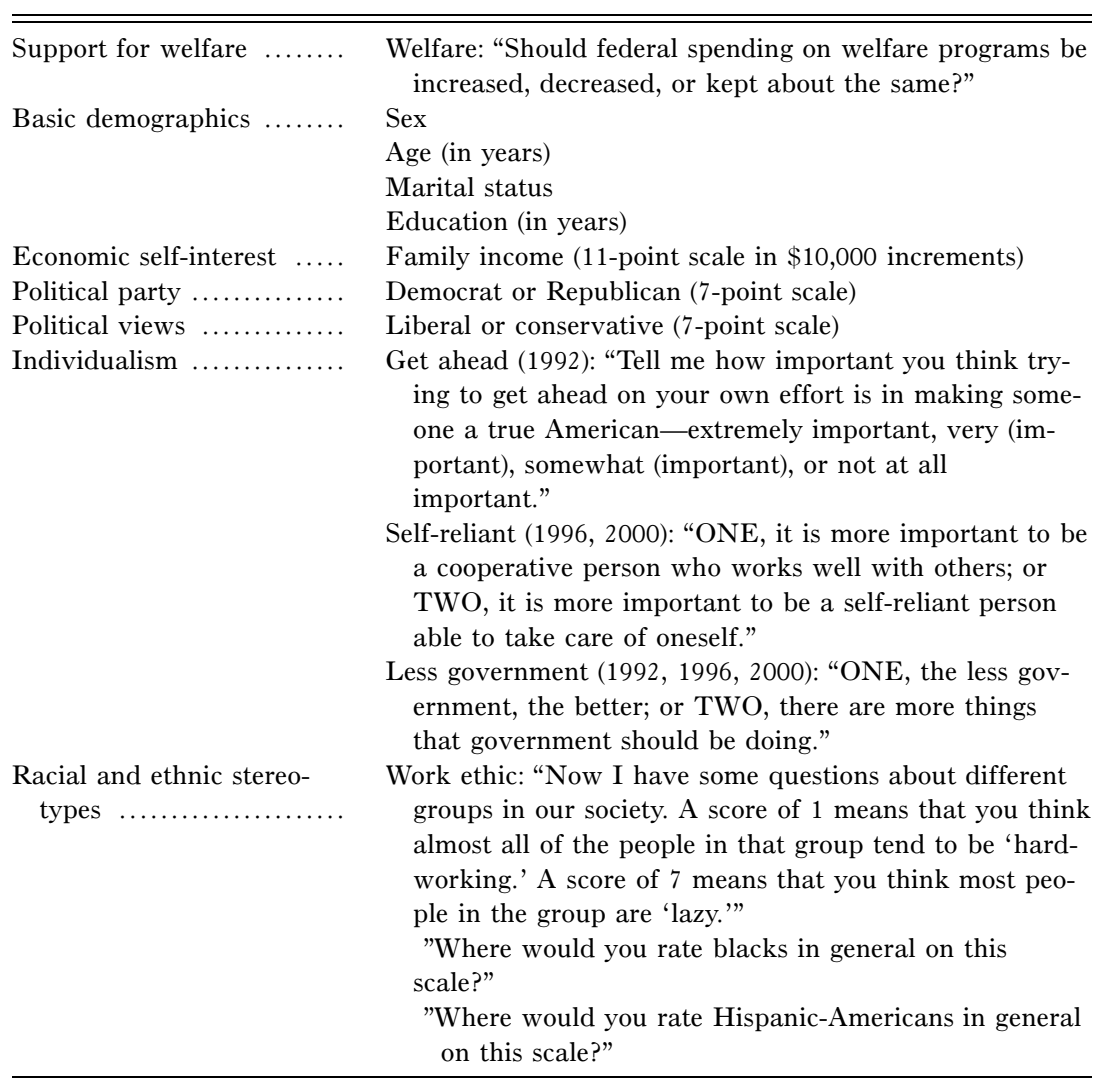




\section{APPENDIX B}

TABLE B1

Means and SDs of Variables before Recoding

\begin{tabular}{|c|c|c|c|c|c|c|}
\hline \multirow[b]{2}{*}{ VARIABLE } & \multicolumn{2}{|c|}{1992 NES } & \multicolumn{2}{|c|}{1996 NES } & \multicolumn{2}{|c|}{2000 NES } \\
\hline & Mean & $\mathrm{SD}$ & Mean & $\mathrm{SD}$ & Mean & $\mathrm{SD}$ \\
\hline Increase welfare & 1.7 & .70 & 1.5 & .65 & 1.7 & .70 \\
\hline Age $\ldots \ldots \ldots \ldots \ldots$ & 46.9 & 17.9 & 48.6 & 17.5 & 48.5 & 17.1 \\
\hline Female & .52 & .50 & .54 & .50 & .55 & .50 \\
\hline Married $\ldots \ldots \ldots \ldots \ldots \ldots$ & .57 & .49 & .57 & .50 & .56 & .50 \\
\hline Education in years $\ldots \ldots \ldots \ldots$ & 13.1 & 2.6 & 13.6 & 2.5 & 13.8 & 2.5 \\
\hline Family income $(\$ 10,000) \ldots \ldots$ & 5.0 & 3.0 & 5.3 & 3.0 & 6.0 & 3.0 \\
\hline Republican ..................... & 3.0 & 2.0 & 3.0 & 2.1 & 3.0 & 2.1 \\
\hline Conservative $\ldots \ldots \ldots \ldots$ & 4.3 & 1.4 & 4.4 & 1.4 & 4.4 & 1.7 \\
\hline Less government $\ldots \ldots \ldots \ldots \ldots$ & .41 & .48 & .53 & .49 & .47 & .50 \\
\hline Get ahead on own ............. & .81 & .39 & $\ldots$ & . & $\ldots$ & $\ldots$ \\
\hline Self-reliant $\quad \ldots \ldots \ldots \ldots \ldots \ldots$ & $\cdots$ & $\ldots$ & .45 & .50 & .45 & .50 \\
\hline \multicolumn{7}{|l|}{ Beliefs: } \\
\hline Whites are lazy & 3.0 & 1.1 & 3.1 & 1.1 & 3.0 & 1.2 \\
\hline Latinos are lazy . & 3.9 & 1.2 & 3.7 & 1.1 & 3.6 & 1.3 \\
\hline Blacks are lazy ..... & 4.2 & 1.2 & 4.1 & 1.2 & 4.1 & 1.2 \\
\hline \%black state $\ldots \ldots \ldots \ldots \ldots \ldots$ & 11.1 & 7.0 & 10.9 & 7.1 & 11.2 & 7.5 \\
\hline \%black county $\ldots \ldots \ldots \ldots \ldots$ & 9.7 & 11.2 & 8.8 & 9.8 & NA & NA \\
\hline \%Hispanic state $\ldots \ldots \ldots \ldots \ldots$ & 8.7 & 9.2 & 9.0 & 9.5 & 8.9 & 9.1 \\
\hline \%Hispanic county .............. & 7.1 & 10.5 & 7.7 & 10.7 & NA & NA \\
\hline
\end{tabular}

TABLE B2

TABle of Correlations, For NES Data, 1992

\begin{tabular}{lrrrrrrrr}
\hline \hline Variable & 1 & 2 & 3 & 4 & 5 & 6 & 7 & 8 \\
\hline 1. Increase welfare $\ldots \ldots \ldots \ldots \ldots \ldots \ldots \ldots \ldots$ & $\ldots$. & & & & & & & \\
2. Believe blacks are lazy $\ldots \ldots \ldots \ldots \ldots \ldots$ & -.15 & & & & & & & \\
3. Believe Latinos are lazy $\ldots \ldots \ldots \ldots \ldots \ldots$ & -.09 & .50 & & & & & & \\
4. Get ahead $\ldots \ldots \ldots \ldots \ldots \ldots \ldots \ldots \ldots \ldots$ & -.13 & .08 & .06 & & & & & \\
5. Less government $\ldots \ldots \ldots \ldots \ldots \ldots \ldots \ldots$ & -.25 & .06 & -.03 & .10 & & & & \\
6. Republican $\ldots \ldots \ldots \ldots \ldots \ldots \ldots \ldots \ldots \ldots$ & -.26 & .04 & .02 & .10 & .35 & & & \\
7. Conservative $\ldots \ldots \ldots \ldots \ldots \ldots \ldots \ldots \ldots \ldots$ & -.29 & .07 & .03 & .15 & .33 & .49 & & \\
8. Family income $\ldots \ldots \ldots \ldots \ldots \ldots \ldots \ldots \ldots$ & -.11 & .01 & -.03 & .01 & .21 & .14 & .08 & $\ldots \ldots \ldots \ldots$ \\
\hline
\end{tabular}


TABLE B3

TABle of Correlations, for NES Data, 1996

\begin{tabular}{|c|c|c|c|c|c|c|c|c|}
\hline Variable & 1 & 2 & 3 & 4 & 5 & 6 & 7 & 8 \\
\hline 1. Increase welfare & $\ldots$ & & & & & & & \\
\hline 2. Believe blacks are lazy $\ldots \ldots \ldots \ldots \ldots$ & -.13 & 1.0 & & & & & & \\
\hline 3. Believe Latinos are lazy $\ldots \ldots \ldots \ldots \ldots$ & -.05 & .50 & & & & & & \\
\hline 4. Self-reliant $\ldots \ldots \ldots \ldots \ldots$ & -.23 & .12 & .03 & & & & & \\
\hline 5. Less government $\ldots \ldots \ldots$ & -.32 & .07 & -.04 & .14 & & & & \\
\hline 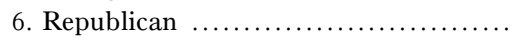 & -.32 & .09 & .01 & .19 & .42 & & & \\
\hline 7. Conservative $\ldots \ldots \ldots \ldots \ldots \ldots \ldots \ldots \ldots$ & -.34 & .14 & .05 & .14 & .36 & .61 & & \\
\hline 8. Family income $\ldots \ldots \ldots \ldots \ldots \ldots \ldots$ & -.17 & -.01 & -.08 & -.00 & .15 & .18 & .04 & \\
\hline
\end{tabular}

TABLE B4

Table of Correlations, NES Data, 2000

\begin{tabular}{|c|c|c|c|c|c|c|c|c|}
\hline Variable & 1 & 2 & 3 & 4 & 5 & 6 & 7 & 8 \\
\hline 1. Increase welfare $\ldots \ldots \ldots \ldots \ldots \ldots \ldots$ & . . . & & & & & & & \\
\hline 2. Believe blacks are lazy $\ldots \ldots \ldots \ldots \ldots$ & -.11 & & & & & & & \\
\hline 3. Believe Latinos are lazy $\ldots \ldots \ldots \ldots \ldots$ & .04 & .43 & & & & & & \\
\hline 4. Self-reliant $\ldots \ldots \ldots \ldots \ldots$ & -.09 & .08 & .11 & & & & & \\
\hline 5. Less government $\ldots \ldots \ldots \ldots \ldots \ldots \ldots$ & -.25 & .04 & -.05 & .07 & & & & \\
\hline 6. Republican ......... & -.18 & .07 & -.05 & .08 & .44 & & & \\
\hline 7. Conservative $\ldots \ldots \ldots \ldots \ldots \ldots \ldots \ldots$ & -.23 & .09 & -.03 & .07 & .39 & .53 & & \\
\hline 8. Family income $\ldots \ldots \ldots \ldots \ldots \ldots \ldots$ & -.10 & -.03 & -.09 & -.05 & .11 & .14 & .05 & $\ldots$ \\
\hline
\end{tabular}




\section{APPENDIX C}

TABLE C1

State Classifications by Racial and Ethnic Context, 1990 and 2000 Censuses

\begin{tabular}{|c|c|c|c|c|c|c|}
\hline \multirow[b]{2}{*}{ State } & \multicolumn{2}{|c|}{ \% WhITE } & \multicolumn{2}{|c|}{$\%$ BLACK } & \multicolumn{2}{|c|}{$\%$ HISPANIC } \\
\hline & 1990 & 2000 & 1990 & 2000 & 1990 & 2000 \\
\hline \multicolumn{7}{|l|}{$\begin{array}{l}\text { Disproportionately } \\
\text { black: }\end{array}$} \\
\hline Alabama .............. & 73 & 70 & 25 & 26 & 1 & 2 \\
\hline Arkansas .............. & 82 & 79 & 16 & 16 & 1 & 3 \\
\hline Florida $\ldots \ldots \ldots \ldots$ & 73 & 65 & 13 & 14 & 12 & 17 \\
\hline Delaware $^{\dagger} \ldots \ldots \ldots \ldots$ & 79 & 73 & 17 & 19 & 2 & 5 \\
\hline Georgia $\ldots \ldots \ldots \ldots \ldots$ & 70 & 63 & 27 & 28 & 2 & 5 \\
\hline Illinois ............. & 75 & 68 & 15 & 15 & 8 & 12 \\
\hline Louisiana $. . . \ldots \ldots . . .$. & 66 & 63 & 31 & 32 & 2 & 2 \\
\hline Maryland ............. & 70 & 62 & 25 & 28 & 3 & 4 \\
\hline Michigan ............. & 82 & 79 & 14 & 14 & 2 & 3 \\
\hline Mississippi* ......... & 63 & 61 & 35 & 36 & 1 & 1 \\
\hline New Jersey..$\ldots \ldots$ & 74 & 66 & 13 & 13 & 10 & 13 \\
\hline New York ........... & 69 & 62 & 14 & 15 & 12 & 15 \\
\hline North Carolina ..... & 75 & 70 & 22 & 21 & 1 & 5 \\
\hline South Carolina* .... & 69 & 66 & 30 & 29 & 1 & 2 \\
\hline Tennessee $\ldots \ldots \ldots \ldots$ & 83 & 79 & 16 & 16 & 1 & 2 \\
\hline Virginia $\ldots . . . \ldots \ldots$ & 76 & 70 & 19 & 19 & 3 & 5 \\
\hline \multicolumn{7}{|l|}{$\begin{array}{l}\text { Disproportionately } \\
\text { Latino: }\end{array}$} \\
\hline Arizona $\ldots \ldots \ldots \ldots$ & 72 & 64 & 3 & 3 & 19 & 25 \\
\hline California $\ldots \ldots \ldots \ldots$ & 57 & 47 & 7 & 6 & 26 & 32 \\
\hline Colorado .............. & 81 & 74 & 4 & 4 & 13 & 17 \\
\hline Florida $\ldots \ldots \ldots \ldots$ & 73 & 65 & 13 & 14 & 12 & 17 \\
\hline Illinois $^{\ddagger} \ldots \ldots \ldots \ldots$ & 75 & 68 & 15 & 15 & 8 & 12 \\
\hline Nevada* ...... & 79 & 65 & 6 & 7 & 10 & 20 \\
\hline New Jersey ${ }^{*} \ldots \ldots$. & 74 & 66 & 13 & 13 & 10 & 13 \\
\hline New Mexico* ...... & 50 & 45 & 2 & 2 & 38 & 42 \\
\hline New York .......... & 69 & 62 & 14 & 15 & 12 & 15 \\
\hline Texas $\ldots . . . \ldots \ldots \ldots$ & 61 & 52 & 12 & 11 & 26 & 32 \\
\hline \multicolumn{7}{|l|}{$\begin{array}{l}\text { Disproportionately } \\
\text { white: }\end{array}$} \\
\hline Connecticut .......... & 84 & 77 & 8 & 9 & 6 & 9 \\
\hline Idaho $^{\dagger} \ldots \ldots \ldots \ldots \ldots$ & 92 & 88 & 0 & 0 & 5 & 8 \\
\hline Indiana $\ldots \ldots \ldots \ldots$ & 90 & 86 & 8 & 8 & 2 & 4 \\
\hline Iowa $\ldots \ldots \ldots \ldots \ldots$ & 96 & 93 & 2 & 2 & 1 & 3 \\
\hline Kansas $\ldots \ldots \ldots \ldots$ & 88 & 83 & 6 & 6 & 4 & 7 \\
\hline Kentucky $^{\dagger} \ldots \ldots \ldots \ldots$ & 92 & 89 & 7 & 7 & 1 & 2 \\
\hline Maine $^{\dagger} \quad \ldots . \ldots \ldots \ldots$ & 98 & 97 & 0 & 1 & 1 & 1 \\
\hline Massachusetts ...... & 88 & 82 & 5 & 5 & 5 & 7 \\
\hline Minnesota ............ & 94 & 88 & 2 & 3 & 1 & 3 \\
\hline Missouri $\ldots \ldots \ldots \ldots$ & 87 & 84 & 11 & 11 & 1 & 2 \\
\hline
\end{tabular}




\section{American Journal of Sociology}

TABLE C1 (Continued)

\begin{tabular}{|c|c|c|c|c|c|c|}
\hline \multirow[b]{2}{*}{ State } & \multicolumn{2}{|c|}{$\%$ White } & \multicolumn{2}{|c|}{$\%$ BLACK } & \multicolumn{2}{|c|}{$\%$ HiSPANIC } \\
\hline & 1990 & 2000 & 1990 & 2000 & 1990 & 2000 \\
\hline Nebraska & 93 & 87 & 4 & 4 & 2 & 6 \\
\hline New Hampshire ... & 97 & 95 & 1 & 1 & 1 & 2 \\
\hline North Dakota $^{\dagger} \ldots$. & 94 & 92 & 1 & 1 & 1 & 1 \\
\hline Ohio $\ldots \ldots \ldots \ldots \ldots$ & 87 & 84 & 11 & 11 & 1 & 2 \\
\hline Oklahoma* ........ & 81 & 74 & 7 & 7 & 3 & 5 \\
\hline Oregon $\ldots \ldots \ldots \ldots$ & 91 & 84 & 2 & 2 & 4 & 8 \\
\hline Pennsylvania ....... & 88 & 84 & 9 & 10 & 2 & 3 \\
\hline South Dakota* ..... & 91 & 88 & 0 & 1 & 1 & 1 \\
\hline Utah* $^{*} \ldots \ldots \ldots \ldots$ & 91 & 85 & 1 & 1 & 5 & 9 \\
\hline Vermont $^{\dagger} \ldots \ldots \ldots \ldots$ & 98 & 96 & 0 & 1 & 1 & 1 \\
\hline Washington ......... & 87 & 79 & 3 & 3 & 4 & 7 \\
\hline West Virginia ....... & 96 & 95 & 3 & 3 & 0 & 1 \\
\hline Wisconsin .......... & 91 & 87 & 5 & 6 & 2 & 4 \\
\hline Wyoming $\ldots \ldots \ldots \ldots$ & 91 & 89 & 1 & 1 & 6 & 6 \\
\hline
\end{tabular}

* State is not in the 1992 data set.

" State is only in the 2000 data set.

${ }^{*}$ New Jersey and Illinois are only included as predominantly Latino states in the 2000 data set.

\section{REFERENCES}

Allport, Gordon W. 1954. The Nature of Prejudice. Cambridge, Mass.: Perseus Books. Ashmore, Richard D., and Frances K. Del Boca. 1981. "Conceptual Approaches to Stereotypes and Stereotyping." Pp. 1-35 in Cognitive Processes in Stereotyping and Intergroup Behavior, edited by David L. Hamilton. Hillsdale, N.J.: Erlbaum.

AuClaire, Philip Arthur. 1984. "Public Attitudes toward Social Welfare Expenditures." Social Work 29:139-44.

Bobo, Lawrence. 1988. "Group Conflict, Prejudice, and the Paradox of Contemporary Racial Attitudes.” Pp. 85-116 in Eliminating Racism: Profiles in Controversy, edited by Phyllis Katz and Dalmas Taylor. New York: Plenum Press.

- 2001. "Racial Attitudes and Relations at the Close of the Twentieth Century." Pp. 264-301 in America Becoming: Racial Trends and Their Consequences, edited by Neil Smelser, William Julius Wilson, and Faith Mitchell. Washington, D.C.: National Academy Press.

Bobo, Lawrence, and Vincent L. Hutchings. 1996. "Perceptions of Racial Group Competition: Extending Blumer's Theory of Group Position to a Multi-Racial Social Context." American Sociological Review 61:951-72.

Bobo, Lawrence, and James R. Kluegel. 1997. "Status, Ideology, and Dimensions of Whites' Racial Beliefs and Attitudes: Progress and Stagnation.” Pp. 93-120 in Racial Attitudes in the 1990s: Continuity and Change, edited by Steven A. Tuch and Jack K. Martin. Westport, Conn.: Praeger.

Bobo, Lawrence, and Michael P. Massagli. 2001. "Stereotypes and Urban Inequality." Pp. 89-162 in Urban Inequality: Evidence from Four Cities, edited by Alice O'Conner, Chris Tilly, and Lawrence D. Bobo. New York: Russell Sage Foundation.

Borjas, George J. 1999. "Immigration and Welfare Magnets." Journal of Labor Economics 17:607-37.

Brown, Michael K. 1999. Race, Money, and the American Welfare State. Ithaca, N.Y.: Cornell University Press. 


\section{Changing Color of Welfare}

Burns, Nancy, Donald R Kinder, Steven J. Rosenstone, Virginia Sapiro, and the National Election Studies. 2001. American National Election Study, 2000: Pre-/PostElection Survey. 2d ICPSR Version. Ann Arbor: University of Michigan, Center for Political Studies (data set); Inter-University Consortium for Political and Social Research (producer and distributor).

Calavita, Kitty. 1996. "The New Politics of Immigration: 'Balanced-Budget Conservatism' and the Symbolism of Proposition 187." Social Problems 43:284-305.

Cavanagh, Thomas E. 2000. "Political Representation and Stratified Pluralism." Pp. 163-94 in Immigration and Race: New Challenges for American Democracy, edited by Gerald D. Jaynes. New Haven, Conn.: Yale University Press.

Clawson, Rosalee A., and Rakuya Trice. 2000. "Poverty as We Know It: Media Portrayals of the Poor." Public Opinion Quarterly 64:53-64.

Congressional Record. 1995. "Debate on the Floor of the House of Representatives about the Personal Responsibility Act of 1995." March 24. Washington, D.C.: Government Printing Office.

Cook, Jay Lomax, and Edith J. Barrett. 1992. Support for the American Welfare State: The Views of Congress and the Public. New York: Columbia University Press.

Davis, James A., and Tom W. Smith. 2000. General Social Surveys, 1972-1990. Chicago: National Opinion Research Center.

Edsall, Thomas Byrne, and Mary D. Edsall. 1992. Chain Reaction: The Impact of Race Rights and Taxes on American Politics. New York: W. W. Norton.

Feldman, Stanley, and John Zaller. 1992. "The Political Culture of Ambivalence: Ideological Responses to the Welfare State." American Journal of Political Science 36:268-307.

Fix, Michael, and Jeffrey Passel. 2002. "The Scope and Impact of Welfare Reform's Immigrant Provisions." Washington, D.C.: Urban Institute.

Fossett, Mark A., and K. Jill Kiecolt. 1989. "The Relative Size of Minority Populations and White Racial Attitudes." Social Science Quarterly 70:820-35.

Fujiwara, Lynn H. 1999. "Asian Immigrant Communities and the Racial Politics of Welfare Reform.” Pp. 100-131 in Whose Welfare, edited by Gwendolyn Mink. Ithaca, N.Y.: Cornell University Press.

Gais, Thomas, and R. Kent Weaver. 2002. "State Policy Choices under Welfare Reform.” Policy Brief No. 21. Washington D.C.: Brookings Institution.

Gilens, Martin. 1995. "Racial Attitudes and Opposition to Welfare." Journal of Politics 57:994-1014.

. 1996a. "Race and Poverty in America: Public Misperception and the American News Media." Public Opinion Quarterly 60:515-41.

- 1996b. "Race Coding and White Opposition to Welfare." American Political Science Review 90:593-604.

- 1999. Why Americans Hate Welfare. Chicago: University of Chicago Press.

Gilliam, Franklin D., Jr., and Shanto Iyengar. 2000. "Prime Suspects: The Influence of Local Television News on the Viewing Public." American Journal of Political Science 44:560-73.

Glaser, James M. 1994. "Back to the Black Belt: Racial Environment and White Racial Attitudes in the South." Journal of Politics 56:21-41.

Hasenfeld, Yeheskel, and Jane A. Rafferty. 1989. "The Determinants of Public Attitudes toward the Welfare State." Social Forces 67:1027-48.

Herrick, Thaddeus. 1996. "Buchanan Shoots from Hip at OK Corral: Immigration's a Hot Topic for GOP." Houston Chronicle, February 27, p. A-1.

Iyengar, Shanto. 1990. "Framing Responsibility for Political Issues: The Case of Poverty." Political Behavior 12:19-40.

. 1991. Is Anyone Responsible? How Television Frames Political Issues. Chicago: University of Chicago Press.

Jackman, Mary K., and Marie Crane. 1986. "'Some of my best friends are black . . . ': 


\section{American Journal of Sociology}

Interracial Friendship and Whites' Racial Attitudes." Public Opinion Quarterly 50: 459-86.

Jaynes, Gerald D., ed. 2000. Immigration and Race: New Challenges for American Democracy. New Haven, Conn.: Yale University Press.

Key, V. O. 1949. Southern Politics in State and Nation. Knoxville: University of Tennessee Press.

Kinder, Donal R., and Tali Mendelberg. 1995. "Cracks in American Apartheid: The Political Impact of Prejudice among Desegregated Whites.” Journal of Politics 57: 402-24.

Lamont, Michele. 2000. The Dignity of Working Men: Morality and the Boundaries of Race, Class, and Immigration. Cambridge, Mass.: Harvard University Press.

Lieberman, Robert C. 1998. Shifting the Color Line: Race and the American Welfare State. Cambridge, Mass.: Harvard University Press.

Lower-Basch, Elizabeth. 2000. TANF "Leavers," Applicants, and Caseload Studies: Preliminary Analysis of Racial Differences in Caseload Trends and Leaver Outcomes. Washington, D.C.: Department of Health and Human Services, Office of the Assistant Secretary for Planning and Evaluation. (Accessed at http://aspe.hhs.gov/ hsp/leavers99/race.htm on January 23, 2004).

Luttmer, Erzo P. 2001. "Group Loyalty and the Taste for Redistribution." Journal of Political Economy 109:500-528.

Marmor, Theodore R., Jerry L. Mashaw, and Philip L. Harvey. 1990. America's Misunderstood Welfare State: Persistent Myths, Enduring Realities. New York: Basic Books.

Massey, Douglas S. 2000. "The Residential Segregation of Blacks, Hispanics and Asians, 1970-1990." Pp. 44-73 in Immigration and Race: New Challenges for American Democracy, edited by Gerald D. Jaynes. New Haven, Conn.: Yale University Press.

Massey, Douglas S., and Nancy A. Denton. 1993. American Apartheid: Segregation and the Making of the Underclass. Cambridge, Mass.: Harvard University Press.

Mead, Lawrence M. 1986. Beyond Entitlement: The Social Obligations of Citizenship. New York: Free Press.

Mehan, Hugh. 1997. "The Discourse of the Illegal Immigration Debate: A Case Study in the Politics of Representation." Discourse and Society 8:249-70.

Mendelberg, Tali. 2001. The Race Card: Campaign Strategy, Implicit Messages and the Norm of Equality. Princeton, N.J.: Princeton University Press.

Miller, Warren E., Donald R. Kinder, Steven J. Rosenstone, and the National Election Studies. 1993. American National Election Study, 1992: Pre-/Post-Election Survey (enhanced with 1990 and 1991 data). Data set. Ann Arbor: University of Michigan, Center for Political Studies (producer and distributor).

Nelson, Thomas E., and Donald R. Kinder. 1996. "Issue Frames and Group-Centrism in American Public Opinion." Journal of Politics 58:1055-70.

Oliver, J. Eric, and Tali Mendelberg. 2000. "Reconsidering the Environmental Determinants of White Racial Attitudes." American Journal of Political Science 44: 574-89.

Peffley, Mark, Jon Hurwitz, and Paul M. Sniderman. 1997. "Racial Stereotypes and Whites' Political Views of Blacks in the Context of Welfare and Crime." American Journal of Political Science 41:30-60.

Quadagno, Jill. 1990. "Race, Class and Gender in the U.S. Welfare State: Nixon's Failed Family Assistance Plan." American Sociological Review 55:11-28. . 1994. The Color of Welfare: How Racism Undermined the War on Poverty. Oxford: Oxford University Press.

Quillian, Lincoln. 1996. "Group Threat and Regional Change in Attitudes toward African Americans.” American Journal of Sociology 102:816-60. 


\section{Changing Color of Welfare}

Rieder, Jonathan. 1985. Canarsie: The Jews and Italians of Brooklyn against Liberalism. Cambridge, Mass.: Harvard University Press.

Rosenstone, Steven J., Donald R. Kinder, Warren Miller, and the National Election Studies. 1997. American National Election Study, 1996: Pre-/Post-Election Survey. Data set. Ann Arbor: University of Michigan, Center for Political Studies (producer and distributor).

Sanchez, George J. 1997. "Face the Nation: Race, Immigration, and the Rise of Nativism in Late Twentieth Century America." International Migration Review 31: 1009-30.

Schuman, Howard. 2000. "The Perils of Correlation, the Lure of Labels, and the Beauty of Negative Results.” Pp. 302-23 in Racialized Politics, edited by David Sears, Jim Sidanius, and Lawrence Bobo. Chicago: University of Chicago Press.

Shaw, Greg M., and Robert Y. Shapiro. 2002. "The Polls-Trends: Poverty and Public Assistance." Public Opinion Quarterly 66:105-28.

Sigelman, Lee, Timothy Bledsoe, Susan Welch, and Michael W. Combs. 1996. "Making Contact? Black-White Social Interaction in an Urban Setting." American Journal of Sociology 101:1306-32.

Skocpol, Theda. 1991. "Targeting within Universalism: Politically Viable Policies to Combat Poverty in the United States." Pp. 411-36 in The Urban Underclass, edited by Christopher Jencks and Paul E. Peterson. Washington, D.C.: Brookings Institution Press.

Soss, Joe, Sanford F. Schram, Thomas P. Vartanian, and Erin O’Brien. 2001. "Setting the Terms of Relief: Explaining State Policy Choices in the Devolution Revolution." American Journal of Political Science 45:378-95.

Taylor, Marylee C. 1998. "How White Attitudes Vary with the Racial Composition of Local Populations: Numbers Count." American Sociological Review 63:512-35.

U.S. Bureau of the Census. 2000. Current Population Survey, Table A: People and Families in Poverty by Selected Characteristics: 1998 and 1999. Washington, D.C.: Government Printing Office.

U.S. Department of Health and Human Services, Office of Planning, Research and Evaluation. 2002. Temporary Assistance to Needy Families: Fourth Annual Report to Congress. Washington, D.C.: Government Printing Office.

Valentino, Nicholas A., Vincent L. Hutchings, and Ismail K. White. 2002. "Cues That Matter: How Political Ads Prime Racial Attitudes during Campaigns." American Political Science Review 96:75-90.

Waldinger, Roger, ed. 2001. Strangers at the Gates: New Immigrants in Urban America. Berkeley and Los Angeles: University of California Press.

Waters, Mary C. 1999. Black Identities: West Indian Immigrant Dreams and American Realities. Cambridge, Mass.: Harvard University Press.

Williams, Lucy A. 1995. "Race, Rat Bites and Unfit Mothers: How Media Discourse Informs Welfare Legislation Debate." Fordham Urban Law Journal 22:1159-96.

Wright, Gerald C., Jr., 1976. "Racism and Welfare Policy in America." Social Science Quarterly 57:718-29. 